\title{
Pliocene to Pleistocene climate and environmental history of Lake El'gygytgyn, Far East Russian Arctic, based on high-resolution inorganic geochemistry data
}

\author{
V. Wennrich ${ }^{1}$, P. S. Minyuk ${ }^{2}$, V. Borkhodoev ${ }^{2}$, A. Francke ${ }^{1}$, B. Ritter ${ }^{1}$, N. R. Nowaczyk ${ }^{3}$, M. A. Sauerbrey ${ }^{1}$, \\ J. Brigham-Grette ${ }^{4}$, and M. Melles ${ }^{1}$ \\ ${ }^{1}$ University of Cologne, Institute of Geology and Mineralogy, Cologne, Germany \\ ${ }^{2}$ Russian Academy of Sciences, Northeast Interdisciplinary Scientific Research Institute, Magadan, Russia \\ ${ }^{3}$ Helmholtz Centre Potsdam, GFZ German Research Centre for Geosciences, Potsdam, Germany \\ ${ }^{4}$ University of Massachusetts, Department of Geosciences, USA
}

Correspondence to: V. Wennrich (volker.wennrich@uni-koeln.de)

Received: 9 September 2013 - Published in Clim. Past Discuss.: 25 October 2013

Revised: 2 May 2014 - Accepted: 26 May 2014 - Published: 23 July 2014

\begin{abstract}
The $3.6 \mathrm{Ma}$ sediment record of Lake El'gygytgyn/NE Russia, Far East Russian Arctic, represents the longest continuous climate archive of the terrestrial Arctic. Its elemental composition as determined by X-ray fluorescence scanning exhibits significant changes since the mid-Pliocene caused by climate-driven variations in primary production, postdepositional diagenetic processes, and lake circulation as well as weathering processes in its catchment.

During the mid- to late Pliocene, warmer and wetter climatic conditions are reflected by elevated $\mathrm{Si} / \mathrm{Ti}$ ratios, indicating enhanced diatom production in the lake. Prior to 3.3 Ma, this signal is overprinted by intensified detrital input from the catchment, visible in maxima of clastic-related proxies, such as K. In addition, calcite formation in the early lake history points to enhanced $\mathrm{Ca}$ flux into the lake caused by intensified weathering in the catchment. A lack of calcite deposition after ca. 3.3 Ma is linked to the development of permafrost in the region triggered by cooling in the midPliocene.

After ca. 3.0 Ma the elemental data suggest a gradual transition to Pleistocene-style glacial-interglacial cyclicity. In the early Pleistocene, the cyclicity was first dominated by variations on the $41 \mathrm{kyr}$ obliquity band but experienced a change to a $100 \mathrm{kyr}$ eccentricity dominance during the middle Pleistocene transition (MPT) at ca. 1.2-0.6 Ma. This clearly demonstrates the sensitivity of the Lake El'gygytgyn record to orbital forcing.
\end{abstract}

A successive decrease of the baseline levels of the redoxsensitive $\mathrm{Mn} / \mathrm{Fe}$ ratio and magnetic susceptibility between 2.3 and 1.8 Ma reflects an overall change in the bottom-water oxygenation due to an intensified occurrence of pervasive glacial episodes in the early Pleistocene. The coincidence with major changes in the North Pacific and Bering Sea paleoceanography at ca. $1.8 \mathrm{Ma}$ implies that the change in lake hydrology was caused by a regional cooling in the North Pacific and the western Beringian landmass and/or changes in the continentality. Further increases in total organic carbon and total nitrogen content after ca. $1.6 \mathrm{Ma}$ are attributed to reduced organic matter decay in the sediment during prolonged anoxic periods. This points to more extensive periods of perennial ice coverage, and thus, to a progressive shifts towards more intense peak glacial periods.

In the course of the Pleistocene glacial-interglacial sequence eight so-called "super-interglacials" occur. Their exceptionally warm conditions are reflected by extreme $\mathrm{Si} / \mathrm{Ti}$ peaks accompanied by lows in $\mathrm{Ti}, \mathrm{K}$, and $\mathrm{Fe}$, thus indicating extraordinary high lake productivity.

\section{Introduction}

Geochemical analysis by X-ray fluorescence (XRF) scanning has become a well-accepted and intensively used analytical method to investigate the elemental composition of 


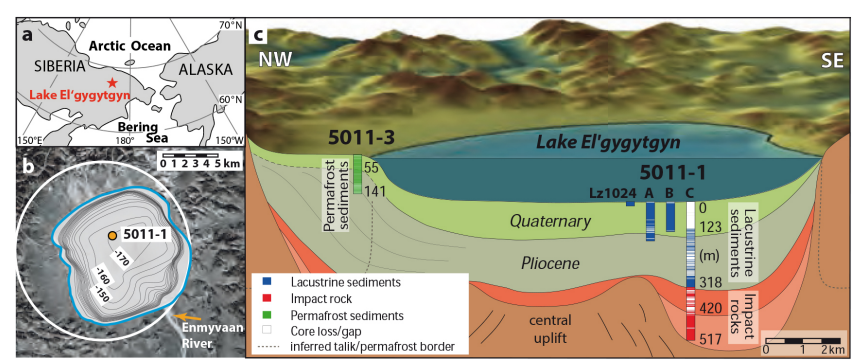

Figure 1. (a) Map showing the location of Lake El'gygytgyn in the western Beringian Arctic, (b) Aerial image of the El'gygytgyn impact crater, bathymetry of Lake El'gygytgyn, and location of ICDP drill site 5011-1. The white circle shows the dimensions of the crater rim, (c) Schematic cross-section of the El'gygytgyn basin stratigraphy with location and recovery of ICDP sites 5011-1 and 5011-3 (modified after Melles et al., 2011). At site 5011-1, three holes (1A, $1 \mathrm{~B}$, and 1C) were drilled to replicate the Pleistocene and uppermost Pliocene sections. Lz1024 is a $16 \mathrm{~m}$ long percussion piston core taken in 2003 that fills the stratigraphic gap between the lake sediment surface and the top of drill cores $1 \mathrm{~A}$ and $1 \mathrm{~B}$.

marine and terrestrial sediments (Rothwell and Rack, 2006). Although not as precise as conventional elemental analyses by inductively coupled plasma optical emission spectrometry (ICP-OES) or conventional XRF, XRF scanning has the advantages of nondestructive analyses combined with minimal sample preparation and short measuring time (Croudace et al., 2006). This makes XRF scanning an outstanding tool for generating records with high resolution, as requested in paleoclimatological and paleoenvironmental sciences (e.g., Brown, 2011; Kujau et al., 2010; Kylander et al., 2007; Yancheva et al., 2007).

The sediment sequence from Lake El'gygytgyn in the Far East Russian Arctic was recovered within the framework of the International Continental Scientific Drilling Program (ICDP) in 2009 (Fig. 1). After the initial lake formation sedimentation commenced ca. 3.58 Ma (Layer 2000), and was interrupted neither by inundation of Cenozoic glaciations nor by desiccation (Melles et al., 2012; Brigham-Grette et al., 2013). Hence, the Lake El'gygytgyn record represents the longest continuous climate archive of the terrestrial Arctic.

Initial work on pilot cores from the lake, covering the past $250-350 \mathrm{ka}$, has proven its unique potential for regional paleoclimate and paleoenvironmental reconstructions (e.g., Brigham-Grette et al., 2007; Lozhkin et al., 2007a, b; Melles et al., 2007; Nowaczyk et al., 2007; Swann et al., 2010; Asikainen et al., 2007). Previous studies have focused on the inorganic geochemistry of the Lake El'gygytgyn sediments of the past 2-3 glacial-interglacial cycles. The results have shown the sediment geochemistry to be highly sensitive to both changes in in-lake processes as well as variations in the lake catchment, like changes in the sediment flux into the lake, primary lake production, anoxia at the lake bottom
(Minyuk et al., 2007, 2011), and hydrologically driven alterations in the sediment grain size (Wennrich et al., 2013).

In this study, we present high-resolution XRF scanning data of the complete $318 \mathrm{~m}$ long lacustrine sediment sequence of Lake El'gygytgyn, thereby extending the existing inorganic geochemistry data to the entire lake history since the mid-Pliocene. Supported by complementary proxy analyses of the record (e.g., Andreev et al., 2013; Francke et al., 2013; Gebhardt et al., 2013; Meyer-Jacob et al., 2013; Sauerbrey et al., 2013; Tarasov et al., 2013; Vogel et al., 2013), the XRF results for the first time enable continuous tracking and differentiation of climate-driven variations of in-lake processes as well as changes in the lake catchment over the past 3.6 Ma. Beyond several highlighted time slices in the record (e.g., Melles et al., 2012; Brigham-Grette et al., 2013; Vogel et al., 2013) the geochemical data presented here shed new light on the climate evolution in western Beringia from the Pliocene warmth to the glacial-interglacial cyclicity of the late Pleistocene in view of orbitally triggered regional and global climate changes.

\section{Study site}

Lake El'gygytgyn $\left(67^{\circ} 30^{\prime} \mathrm{N}, 172^{\circ} 05^{\prime} \mathrm{E}\right.$; Fig. 1) is an arctic lake located in central Chukotka, Far East Russian Arctic. The lake basin was formed by a meteorite impact $3.58 \pm 0.04 \mathrm{Ma}$ (Layer, 2000) that hit into Upper Cretaceous ignimbrites, tuffs and andesite-basalts of the OkhotskChukchi Volcanic Belt (OCVB) (Belyi and Raikevich, 1994; Gurov et al., 2007). With its diameter of ca. $12 \mathrm{~km}$, Lake El'gygytgyn has a surface area of ca. $110 \mathrm{~km}^{2}$ (Nolan and Brigham-Grette, 2007) and fills the deepest part of the ca. $18 \mathrm{~km}$ wide impact crater (Gurov et al., 2007). Approximately 50 ephemeral streams drain the lake catchment of $293 \mathrm{~km}^{2}$ confined by the crater rim (Nolan et al., 2003). The inlet streams annually deliver ca. $0.11 \mathrm{~km}^{3}$ of water and 350 $\mathrm{t}$ of sediment to the lake, mainly from snowmelt (Fedorov et al., 2013). The lake has a single outlet, the Enmyvaam River, leaving the lake in the south and flowing towards the southeast via the Anadyr River into the Bering Sea (Nolan and Brigham-Grette, 2007).

Lake El'gygytgyn is located in an area that is influenced by both Siberian and North Pacific air masses (Barr and Clark, 2011; Yanase and Abe-Ouchi, 2007). The climate at the lake is cold and dry, with mean annual air temperature and annual precipitation of $-10.4^{\circ} \mathrm{C}$ and $73-200 \mathrm{~mm}$, respectively (Nolan and Brigham-Grette, 2007; Nolan, 2013). A comparison of the local climate data to NCEP/NCAR reanalysis data yielded a good correspondence, indicating the local climate at the lake to be representative of the regional climate patterns over western Beringia (Nolan, 2013). The wind pattern at Lake El'gygytgyn today is characterized by strong winds from the north or south, with a mean hourly wind speed of 
$5.6 \mathrm{~m} \mathrm{~s}^{-1}$ but peak values of up to $21.0 \mathrm{~m} \mathrm{~s}^{-1}$ (Nolan and Brigham-Grette, 2007).

Due to the cold Arctic climate, the oligo- to ultraoligotrophic and cold-monomictic Lake El'gygytgyn (Cremer and Wagner, 2003) is fully ice-covered for almost nine months of the year, from mid-October until early to mid-July (Nolan et al., 2003). Since the ice cover during winter prevents a wind-driven mixing of the water column and effectively reduces the gas exchange with the atmosphere, ongoing organic matter decay at the sediment surface causes the bottom waters to become partially oxygen-depleted during the ice-covered season (Cremer et al., 2005). Full mixis of the water body driven by descending warmer shore waters and accompanied by complete bottom-water oxygenation initiates shortly after snowmelt and the initial ice breakup (Nolan and Brigham-Grette, 2007). During the ice-free season, a wind-induced two-cell current system as inferred from surface sediment samples is thought to drive the circulation in Lake El'gygytgyn and supports the transport of coarse-grained material to the lake center (Nolan and Brigham-Grette, 2007; Wennrich et al., 2013). Hydrological modeling approaches yielded a residence time of the modern lake water of ca. 100 years (Fedorov et al., 2013).

Lake El'gygytgyn today has a roughly bowl-shape morphology with a maximum water depth of $175 \mathrm{~m}$ (Nolan and Brigham-Grette, 2007). Multiple paleoshorelines in the north and prominent lake terraces at 35-40, 9-11, and 3-5 m above as well as $10 \mathrm{~m}$ below the modern water level point to significant lake-level variations throughout the lake history (Glushkova and Smirnov, 2007; Schwamborn et al., 2006, 2008a; Juschus et al., 2011).

The surrounding of Lake El'gygytgyn is affected by 330$360 \mathrm{~m}$ deep continuous permafrost (Glushkova and Smirnov, 2007; Mottaghy et al., 2013), whose initial formation is suggested to be linked to a mid-Pliocene cooling event (Brigham-Grette et al., 2013). Permafrost processes in the lake's surroundings, such as cryogenic weathering, as well as slope dynamics and fluvial outwash are the main drivers of physical erosion in the catchment and sediment transport into the lake basin (Schwamborn et al., 2008b), and thus have a strong influence on the composition of the lacustrine sediments.

\section{Material and methods}

\subsection{Field work and core preparation}

The $318 \mathrm{~m}$ thick sediment sequence of Lake El'gygytgyn was cored within the framework of the ICDP El'gygytgyn Drilling Project in spring 2009 (Melles et al., 2011, 2012; Brigham-Grette et al., 2013). Drilling was conducted from an artificially thickened lake-ice cover using a modified GLAD 800 system ("Russian GLAD 800") operated by the US consortium DOSECC (Melles et al., 2011). At drill site 5011-1 in

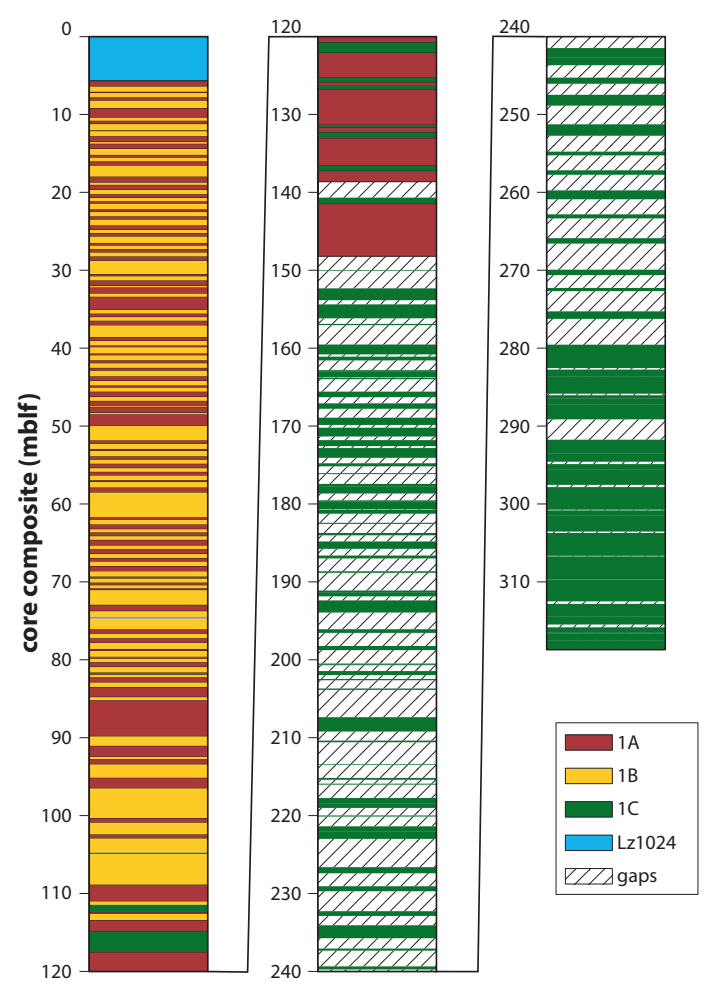

Figure 2. Core composite profile of the lacustrine basin infill of Lake El'gygytgyn illustrating the origin of the interval used from holes $1 \mathrm{~A}, 1 \mathrm{~B}$, and $1 \mathrm{C}$ and pilot core Lz1024. Shaded section are gaps in the composite profile.

the lake center, a total of 3 overlapping holes $-1 \mathrm{~A}, 1 \mathrm{~B}$, and $1 \mathrm{C}$ - were drilled to depths of 147,112 , and $525 \mathrm{~m}$ below lake floor (mblf), respectively (Figs. 1c, 2). In hole 5011-1C, the base of the lacustrine sediments was reached at 318 mblf.

The cores were treated according to a core handling protocol adapted from Ohlendorf et al. (2011). In the laboratories in Cologne, the plastic core liners housing the up to $1 \mathrm{~m}$ long core segments were split lengthwise with a manual core splitter. Subsequently, the sediment was cut into a working and an archive half using a guitar string. For the lower, more compacted sediments of Lake El'gygytgyn, a diamond band saw was used to cut both the plastic liner and the sediment at once. The surface of the core halves was carefully cleaned and levelled by swiping perpendicular to the core axes with standard microscope slides. After cleaning, highresolution digital images of the fresh surfaces of both halves were taken using a MSCL-CIS benchtop core imaging system (Geotek Ltd.), and the cores were described for color, grain size, and sedimentary structure to define initial sedimentary facies (Melles et al., 2012; Brigham-Grette et al., 2013; Sauerbrey et al., 2013). Further measurements and the subsampling were conducted on the working halves, whereas the archive halves were stored for future analyses. 


\subsection{Composite profile compilation}

The core sequence of Lake El'gygytgyn is composed of a variety of mainly clastic sediments that can be subdivided into five different facies (A through E; Brigham-Grette et al., 2013). Facies A is characterized by fine-scale lamination formed from alternating dark grey to black silt and clay horizons. The preservation of the laminated sediment texture is assigned to the lack of bioturbation due to anoxia during phases of multiyear lake ice coverage, which represent peak glacial conditions (Melles et al., 2007, 2012). In contrast to facies $\mathrm{A}$, the majority of the sediments deposited during glacial to interstadial and interglacial periods consist of silts of facies B that have a massive to faintly banded structure. Facies $\mathrm{C}$ consists of laminated reddishbrown silt and has been assigned to peak interglacial conditions. In the lowermost section of the core laminated intervals of grey silt to clay as well as sections of alternating grey to reddish-brown clay, silt and fine sand with intermittent brecciated intervals of facies D and $\mathrm{E}$, respectively, occur (Brigham-Grette et al., 2013).

Based on the visual core description, including the identification of prominent mass movement deposits (MMDs; Sauerbrey et al., 2013), tephra layers (Bogaard et al., 2014), and fossil redox layers, in combination with initial logging data, a core composite profile of the three holes of site 50111 was compiled for subsequent sampling. In detail, we performed a layer-by-layer correlation of the overlapping core sections, and, if possible, only included the central part of a section in the composite to avoid disturbance at section cuts. Correlation between the ICDP drill cores and pilot core Lz1024 covering the past 350 ky (Nowaczyk et al., 2013; Juschus et al., 2007; Frank et al., 2013) revealed that ICDP site 5011-1 starts at a subbottom depth of 5.67 mblf. The gap to the sediment surface was filled with core Lz1024 (Fig. 2). Between 5.67 and $104.80 \mathrm{mblf}$ the core composite exclusively originates from holes $1 \mathrm{~A}$ and $1 \mathrm{~B}$, whereas holes $1 \mathrm{~A}$, $1 \mathrm{~B}$, and $1 \mathrm{C}$ were spliced between 104.80 and $113.40 \mathrm{mblf}$, and $1 \mathrm{~A}$ and $1 \mathrm{C}$ were used between 113.40 and $145.70 \mathrm{mblf}$ (Nowaczyk et al., 2013; Fig. 2). Below a composite depth of 145.70 mblf down to the base of the lacustrine sediments at 318 mblf, only sediments of hole $1 \mathrm{C}$ are available. The core recovery for the Pleistocene section above 123 mblf is almost complete $(99.81 \%)$, but is much lower in the lowermost section (50.54\%; Fig. 2).

In order to investigate the long-term sedimentation history in Lake El'gygytgn, volcanic ash layers and distinct MMDs with thicknesses exceeding $5 \mathrm{~cm}$ were defined as gaps in the pelagic record and excluded from the composite profile. These intervals were afterwards omitted from the routine sampling, but a detailed analysis of the MMDs is presented in Sauerbrey et al. (2013). A detailed compilation of the sections used for the composite profile is presented in Table S1 in the Supplement.

\subsection{XRF scanning}

High-resolution elemental analyses of the sediments were performed by energy-dispersive X-ray fluorescence (XRF) on the working half of each core segment using an ITRAX core scanner (Cox Analytical, Sweden) at the University of Cologne. The ITRAX system is a multifunction corescanning instrument that enables nondestructive recording of optical, radiographic, and chemical variations of sediment cores (Croudace et al., 2006). Each core was scanned two times at $2 \mathrm{~mm}$ intervals, first with the ITRAX equipped with a $3.0 \mathrm{~kW}$ molybdenum (Mo) X-ray source, and subsequently with a $1.9 \mathrm{~kW}$ chromium $(\mathrm{Cr}) \mathrm{X}$-ray source in order to generate higher count rates and lower detection limits for heavier ( $\mathrm{Mn}$ to $\mathrm{U}$ ) and lighter elements ( $\mathrm{Al}$ to $\mathrm{Ti}$ ), respectively. In the case of the Lake El'gygytgyn sediments, both scans were conducted with a tube voltage of $30 \mathrm{kV}$, a current of $30 \mathrm{~mA}$, and an integration time of $10 \mathrm{~s}$. Element data recorded by the ITRAX are semiquantitative, and are expressed as total counts (ct), i.e., integrated peak areas, or as element count ratios. Spectra evaluation and postprocessing was performed with the software QSpec 6.5 (Cox Analytical, Sweden). The mathematical model used was tuned to best fit the measured data by adjusting sample matrix characteristics, element composition, and tube as well as detector parameters.

The element-specific response to variations in the tube power, i.e., as a result of tube ageing during long-term measurements, were monitored by routinely scanning a standard reference glass of known composition after each core section (Ohlendorf et al., 2014). For elements of mid- to high atomic number $(Z)$ and heavy elements $(Z \geq 37)$, the element intensities were corrected for drifts due to tube ageing or shifts in the signal after tube changes by normalizing with the Compton (incoherent) scatter. For lighter elements, ratios of element intensities with comparable atomic numbers were instead calculated, which has been shown to be more useful than tube corrections (Ohlendorf et al., 2014).

In addition to variations in the energy of the excitation source, the element intensities derived from the wet half cores, especially those of light elements such as $\mathrm{Si}$, might be influenced by effects of the sediment matrix (Löwemark et al., 2011). In the case of Lake El'gygytgyn, a comparative XRF scanning study performed on 329 samples of both wet and untreated as well as freeze-dried and powered material, in combination with wavelength dispersive XRF (WDXRF) analyses of material fused with lithium tetraborate, demonstrates the matrix effects to predominantly bias the $\mathrm{Si}$, and to a lesser degree also the Al signal, whereas for heavier elements the matrix effects were rather negligible (Melles et al., 2012). The results suggest these matrix effects are induced and/or amplified by the highly variable diatom contents and the porous structure of diatom frustrules. To correct the $\mathrm{Si}$ data for the matrix effects, an empirically determined matrix correction based on an exponential attenuation function between the ratio of wet and dry element intensities and the 
ITRAX-derived ratio of Compton and Rayleigh scattering (inc/ coh ratio) was applied using the formula

$\mathrm{Si}_{\mathrm{mc}}=\frac{\mathrm{Si}_{\text {raw }}}{3.2994 \times e^{0.505 \times \mathrm{inc} / \mathrm{coh}}}$,

with $\mathrm{Si}_{\text {raw }}$ being the raw and $\mathrm{Si}_{\mathrm{mc}}$ the matrix-corrected $\mathrm{Si}$ integrals (Melles et al., 2012). The inc/ coh ratio used in the formula is, in general, dependent on the average atomic number of the sample, and thus is reported to be indicative of organic matter content and/or matrix-induced density variations (Guyard et al., 2007).

\subsection{TOC, TIC}

The total carbon (TC) and total inorganic carbon (TIC) contents were determined with a DimaTOC 100 carbon analyzer (Dimatec Corp., Germany) after suspending $20 \mathrm{mg}$ of sediment in $10 \mathrm{~mL}$ DI water using a disperser. While TC was directly measured as $\mathrm{CO}_{2}$ after combustion of the suspended sediment at $900{ }^{\circ} \mathrm{C}$, TIC was determined as $\mathrm{CO}_{2}$ at $160^{\circ} \mathrm{C}$ after treating with phosphoric acid $\left(\mathrm{H}_{3} \mathrm{PO}_{4}\right)$. The total organic carbon (TOC) content was calculated from the difference between the measured TC and TIC contents. Total nitrogen $(\mathrm{TN})$ contents were measured with an elemental analyzer (vario micro cube, elementar Corp.) after combustion at $1150^{\circ} \mathrm{C}$.

\subsection{Age model}

The age-depth model for the Lake El'gygytgyn composite profile is primarily based on well-dated polarity changes in the paleomagnetic inclination (Haltia and Nowaczyk, 2013) and the age of the crater of $3.58 \pm 0.04 \mathrm{Myr}$ (Layer, 2000). It was further refined by tuning to both the $65^{\circ} \mathrm{N}$ summer insolation (Laskar et al., 2004) and the global marine isotope stack (Lisiecki and Raymo, 2005) using magnetic susceptibility (MS), TOC and biogenic silica (BSi) contents, pollen data, the $\mathrm{Si} / \mathrm{Ti}$ ratio, color hues, and grain-size parameters (Nowaczyk et al., 2013).

\subsection{Time series analyses}

For time series analysis of the $\mathrm{Rb} / \mathrm{Sr}$ ratio data, the bulk spectrum of the temporally unevenly spaced data was calculated using the software REDFIT (Schulz and Mudelsee, 2002). Evolutionary spectra of the $\mathrm{Rb} / \mathrm{Sr}$ data were plotted with the software package ESALAB, which uses the same algorithm as REDFIT (Weber et al., 2010).

\section{Results and discussion}

\subsection{Element composition}

As demonstrated in earlier studies for the past ca. 250, 340 , and $440 \mathrm{kyr}$, the elemental composition of the sediment record in Lake El'gygytgyn is highly variable and strongly fluctuates on glacial-interglacial timescales (Frank et al., 2013; Minyuk et al., 2007, 2011, 2014, Nowaczyk et al., 2002, 2007). Further below, we present the results of selected indicative elements and element ratios and discuss their distribution over the entire Pliocene-Pleistocene sediment record with respect to changes in the detrital flux, bioproduction, sediment transport, and diagenetic sediment alteration.

\subsubsection{Ti, K, Ca}

Although being a minor element in Lake El'gygytgyn sediments, titanium has proven to be a useful indicator of the climatic history of the lake and its catchment of the past ca. 250 and 340 kyr (Minyuk et al., 2007, 2014). Throughout the entire lake sediment record, Ti exhibits highly variable signal amplitudes with typically lower values between ca. 5000 and 9000 ct during normal interglacials, peak minima down to ca. 3000 ct during peak interglacials, and maxima between 12000 and $18000 \mathrm{ct}$ during cold stages (Figs. 3, 4). As a relatively immobile element, titanium occurs as an abundant component in a variety of mineral phases (e.g., rutile, sphen, titano-magnetite), and thus is commonly linked to detrital input (e.g., Haug et al., 2001; Yancheva et al., 2007). Therefore, it has been used in lacustrine sediments to reconstruct the intensities of catchment erosion and detrital input (Panizzo et al., 2008; Whitlock et al., 2008). In Lake El'gygytgyn sediments, correlation analyses of Ti intensities to grain-size results by Francke et al. (2013) yield a moderate to high correspondence to the fine silt fraction $(R=0.68 ; n=858)$, but a weaker or even anticorrelation to other grain-size classes (Table 1). A similar enrichment of $\mathrm{Ti}$ in the fine fraction has been reported for the last $440 \mathrm{kyr}$ of the record and explained by enhanced deposition of Ti-bearing chlorite during glacial conditions (Minyuk et al., 2014). In interglacial sediments, in contrast, the clay mineralogy is rather dominated by smectite and illite (Asikainen et al., 2007). The Ti occurrence in these sediments has been primarily attributed to the presence of titanomagnetite (Murdock et al., 2013), whose generally low abundance likely explains the Ti depletion during warm stages. In addition, simultaneous minima in $\mathrm{Ti}, \mathrm{K}$, and $\mathrm{Ca}$, as well as in most other elements, during peak interglacials strongly suggest a significant dilution effect by biogenic opal especially in peak interglacial sediments (Melles et al., 2012). Although also notable, this dilution effect on the Ti signal is less severe in conventional XRF data (Minyuk et al., 2014), thus suggesting that it is amplified by matrix effects in untreated sediment due to higher water contents of the opal-rich sediment, leading to further scattering of the primary $\mathrm{X}$ radiation.

Compared to titanium, the potassium signal shows a lower variability in the amplitudes over the Lake El'gygytgyn sediment record (Fig. 3). Intensities range between 15000 and $21000 \mathrm{ct}$, except for some distinct lows during peak 
Table 1. Pearson $(r)$ correlation coefficients for selected elements and element ratios measured by XRF core scanning vs. the mean grain size and percentages of selected grain-size classes of samples from Lake El'gygytgyn $(n=858)$. Correlation coefficients above 0.5 (bold) and below -0.5 (italic) are indicated.

\begin{tabular}{lrrrrrrrrrr}
\hline & $\mathrm{Si}$ & $\mathrm{Ti}$ & $\mathrm{K}$ & $\mathrm{Ca}$ & $\mathrm{Mn}$ & $\mathrm{Fe}$ & $\mathrm{Mn} / \mathrm{Fe}$ & $\mathrm{Rb}$ & $\mathrm{Sr}$ & $\mathrm{Rb} / \mathrm{Sr}$ \\
\hline Mean $(\mu \mathrm{m})$ & 0.03 & -0.50 & -0.06 & 0.21 & -0.03 & -0.48 & 0.16 & -0.09 & 0.21 & -0.64 \\
Medium sand & 0.02 & -0.01 & 0.02 & 0.01 & -0.01 & -0.04 & 0.00 & -0.03 & -0.02 & -0.03 \\
Fine sand & -0.02 & -0.06 & -0.09 & -0.12 & -0.01 & -0.09 & 0.02 & -0.07 & -0.03 & -0.09 \\
Very fine sand & 0.10 & -0.45 & 0.02 & 0.31 & -0.02 & -0.43 & 0.17 & -0.07 & 0.20 & -0.58 \\
Very coarse silt & -0.01 & -0.63 & -0.11 & 0.16 & -0.08 & -0.56 & 0.12 & 0.00 & 0.30 & -0.70 \\
Coarse silt & 0.02 & -0.42 & -0.12 & 0.17 & -0.04 & -0.42 & 0.12 & -0.10 & 0.18 & -0.58 \\
Medium silt & -0.04 & 0.40 & -0.11 & -0.14 & 0.12 & 0.27 & 0.02 & -0.23 & -0.25 & 0.19 \\
Fine silt & -0.05 & $\mathbf{0 . 6 8}$ & 0.03 & -0.27 & 0.11 & $\mathbf{0 . 5 9}$ & -0.10 & -0.04 & -0.32 & $\mathbf{0 . 6 6}$ \\
Very fine silt & 0.00 & $\mathbf{0 . 5 6}$ & 0.15 & -0.14 & 0.04 & $\mathbf{0 . 5 2}$ & -0.15 & 0.05 & -0.25 & $\mathbf{0 . 6 8}$ \\
\hline
\end{tabular}

interglacials due to opal diution (e.g., MIS 11.3: ca. $3400 \mathrm{ct}$ ). The long-term record shows relatively constant $\mathrm{K}$ values back to ca. 2.0 Ma, whereas in the older sediments two periods with significantly reduced $\mathrm{K}$ counts occur between 2.60 and 2.00 and between ca. 3.48 and 3.10 Ma (Fig. 3).

Potassium in the Lake El'gygytgyn sediments partly derives from orthoclase $\left(\mathrm{KAlSi}_{3} \mathrm{O}_{8}\right)$, which abundantly occurs as phenocrysts in both rhyolitic and andesitic volcanic rocks of the lake catchment (Belyi, 2010; Gurov et al., 2005). Bulk mineral analyses of modern lake sediments and bedrock samples yielded orthoclase contents of up to 8.4 and $10.4 \%$, respectively (Wennrich et al., 2013). According to these results as well as downcore investigations, these feldspars are enriched in the coarse fraction of Lake El'gygytgyn sediments as a result of cryogenic weathering in the active layer of the permafrost (Schwamborn et al., 2008b; Wennrich et al., 2013). The transport of coarse material to deeper parts of the lake is reported to be triggered by the existence of a wind-induced current system, which is restricted to interglacial periods (Francke et al., 2013; Wennrich et al., 2013). Another important $\mathrm{K}$ source in Lake El'gygytgyn sediments is illite $\left(\mathrm{K}_{0.65} \mathrm{Al}_{2.0}\left[\mathrm{Al}_{0.65} \mathrm{Si}_{3.35} \mathrm{O}_{10}\right] \times(\mathrm{OH})\right.$, which accounts for up to $12.8 \%$ of the mineral spectrum in surface samples (Minyuk et al., 2007; Wennrich et al., 2013), and is the major clay mineral in the sediments, predominantly deposited during warm stages (Asikainen et al., 2007). The opponent occurrence of fine-grained illite and coarse-grained feldspar in the record tends to limit the potential grain-size dependency of K intensities in the Lake El'gygytgyn sediment record (Table 1).

Like potassium, calcium shows relatively small fluctuations throughout most of the record (Fig. 3). In contrast to $\mathrm{K}$, however, Ca rather steadily decreases from ca. $14000 \mathrm{ct}$ in the latest Pliocene deposits down to ca. $5000 \mathrm{ct}$ in the youngest Pleistocene section, with pronounced minima of only ca. $3400 \mathrm{ct}$ during the Pleistocene peak interglacials. In addition, $\mathrm{Ca}$ exhibits strongly increased values of up to ca. 210000 in the mid-Pliocene sediments formed prior to ca. $3.25 \mathrm{Ma}$.
In close resemblance to $\mathrm{K}, \mathrm{Ca}$ is primarily associated with feldspars, mainly oligoclase and andesine (both $\left.(\mathrm{Na}, \mathrm{Ca})\left[\mathrm{Al}(\mathrm{Si}, \mathrm{Al}) \mathrm{Si}_{2} \mathrm{O}_{8}\right]\right)$ from the catchment bedrocks, and Ca-bearing smectite as a typical interglacial clay mineral (Asikainen et al., 2007), thus explaining the low grain-size dependency of the Ca signal (Table 1). The strongly enriched $\mathrm{Ca}$ values in the sediments deposited prior to $3.25 \mathrm{Ma}$ are traced back to additional calcite $\left(\mathrm{CaCO}_{3}\right)$ accumulation in the early lake history. This suggestion is confirmed by simultaneously enhanced TIC contents (up to $4.9 \%$; Fig. 3) and the detection of calcite by Fourier transform infrared spectroscopy (FTIRS) analyses in the basal lake sediments (Meyer-Jacob et al., 2014). Observations of calcite-cemented sediment horizons in the lower core section indicate a postdepositional precipitation of the calcite from pore water. The occasional occurrence of TIC in the younger sediments (Fig. 3), in contrast, is interpreted to reflect the formation of other carbonate minerals, like siderite or rhodochrosite, since TIC and Ca show only limited to no correspondence and calcite was not identified by FTIRS analyses in these sediments. The deposition of calcite restricted to the early lake history may be associated with an initial supply from the underlying impactites and volcanic bedrocks, which, according to analyses on respective rocks in the drill core from ICDP Site 5011-1C, contain calcitic vein fillings (Raschke et al., 2013a, b).

\subsubsection{Si}

Silicon is the main component in the elemental spectrum of the Lake El'gygytgyn sediments. Si concentrations determined by wavelength dispersive XRF in the uppermost ca. $440 \mathrm{kyr}$ of the Lake El'gygytgyn record $(n=340)$ range from 57.0 to $80.5 \%$ (Minyuk et al., 2014). The $\mathrm{Si}_{\mathrm{mc}}$ intensities from XRF scanning derived after application of the empirical correction function for combined matrix effects to the $\mathrm{Si}_{\text {raw }}$ data (Melles et al., 2012) correlate well with these data, yielding a coefficient of determination $\left(R^{2}\right)$ of 0.57 . The $\mathrm{Si}_{\mathrm{mc}}$ intensities throughout the entire record vary between ca. 170 


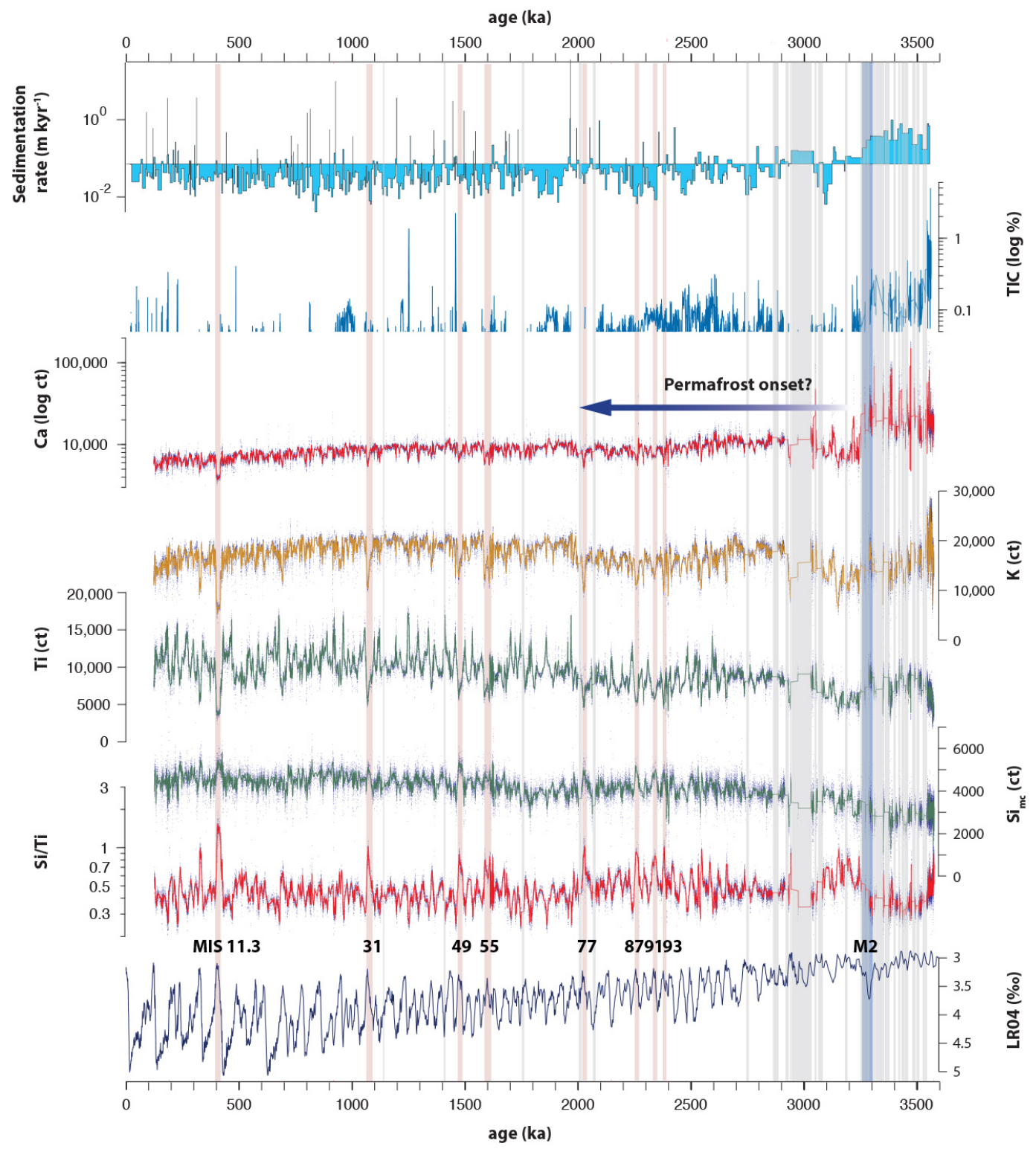

Figure 3. Matrix-corrected $\mathrm{Si}$ intensity $\left(\mathrm{Si}_{\mathrm{mc}}\right), \mathrm{Si} / \mathrm{Ti}$ ratios, $\mathrm{K}$, Ti, and Ca intensity determined by XRF core scanning as well total inorganic carbon (TIC) content and sedimentation rate in the sediment record from Lake El'gygytgyn vs. age compared with the LR04 global marine isotope stack. XRF data are plotted as raw data (blue dots) and 101-point weighted running average (colored lines). "Super-interglacials" at Lake El'gygytgyn and the mid-Pliocene M2 cooling event are highlighted with red and blue bars, respectively. Gaps in the record are shaded with grey bars. Please note the logarithmic scaling of the Ca scale.

and $6900 \mathrm{ct}$ (Fig. 3). During the late Pliocene and early Pleistocene ( $<2.7 \mathrm{Ma}), \mathrm{Si}_{\mathrm{mc}}$ intensities show rather constant long-term averages, but slightly depressed counts between ca. 1.9 and 1.6 Ma. Further on, strong short-term fluctuations of $\mathrm{Si}_{\mathrm{mc}}$ can be mainly attributed to glacial-interglacial variations. The early lake history prior to $3.2 \mathrm{Ma}$, in contrast, is reflected by strongly decreased $\mathrm{Si}_{\mathrm{mc}}$ values.

$\mathrm{Si}$ in lakes is related to either detrital or biological sources (Peinerud, 2000). In the sediment record of Lake El'gygytgyn, the BSi content varies from less than $5 \%$ up to
$56.1 \%$ (Melles et al., 2012), and is primarily the remains of diatom frustules. Diatom analyses of the past 1.2 Myr (Snyder et al., 2013) have shown only minor variations in diatom preservation, thus making the BSi concentration a valuable proxy for in-lake biological primary production. To discriminate detrital and biological Si sources in the elemental composition, the $\mathrm{Si}_{\mathrm{mc}}$ intensities were corrected for titanium that exclusively occurs in the clastic sediment fraction. Previous studies have demonstrated the $\mathrm{Si} / \mathrm{Ti}$ ratio to be a reliable indicator of the BSi content (e.g., Brown, 2011; Brown et 


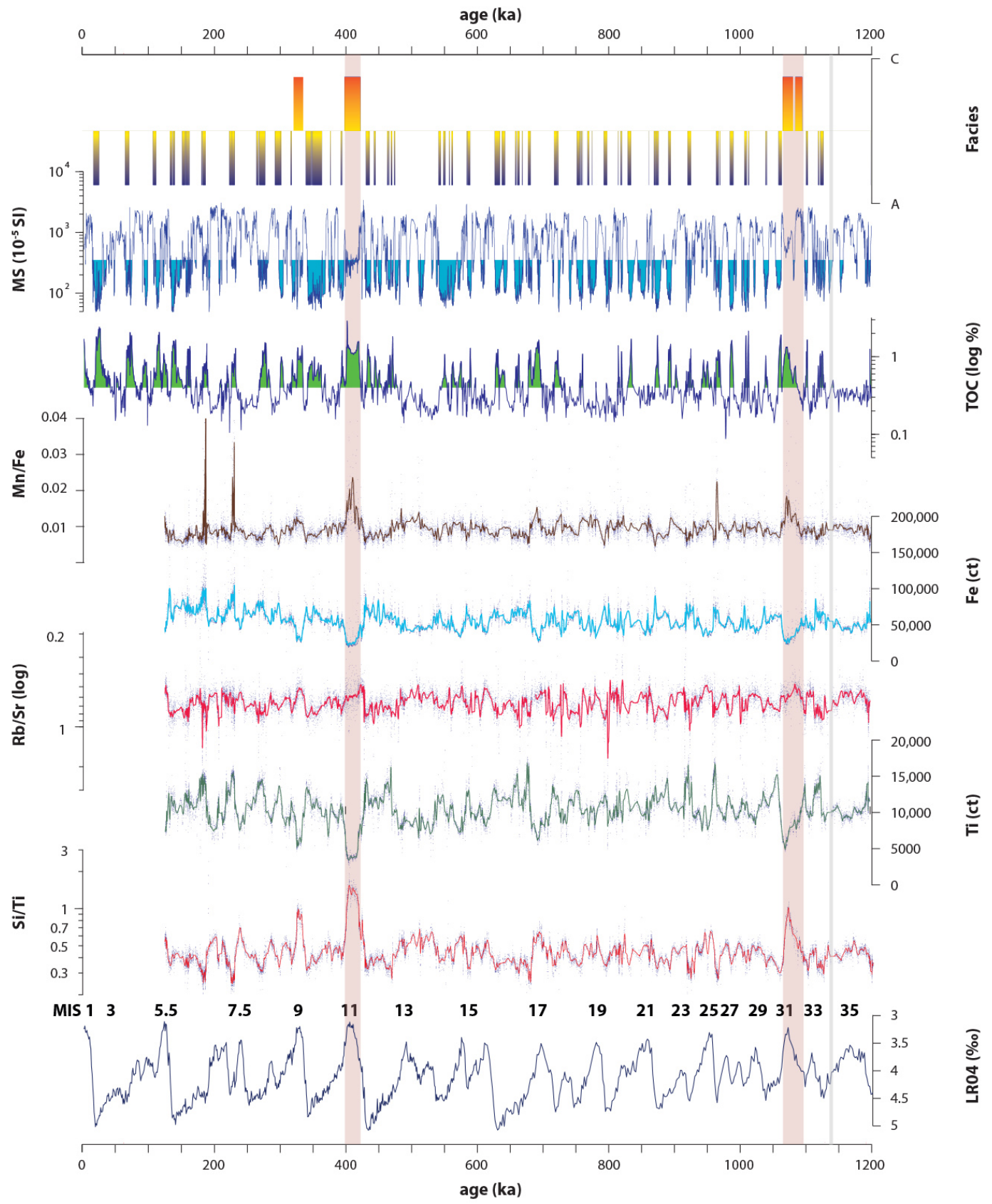

Figure 4. Expanded section of the past 1.2 Myr showing XRF-scanning-derived Si / Ti ratios, Ti intensities, $\mathrm{Rb} / \mathrm{Sr}$ ratios, Fe intensities, and $\mathrm{Mn} / \mathrm{Fe}$ ratios as well as magnetic susceptibility (MS; Nowaczyk et al., 2013), total organic carbon (TOC), and the occurrence of sediment facies $\mathrm{A}$ and $\mathrm{C}$ in the sediment record from Lake El'gygytgyn vs. age compared with the LR04 global marine isotope stack. XRF data are plotted as raw data (blue dots) and 101-point weighted running average (colored lines). "Super-interglacials" MIS 31 and 11.3 at Lake El'gygytgyn are highlighted with red bars. Gaps in the record are shaded with grey bars. Please not the logarithmic scaling of the TOC and MS scales, and the inverse logarithmic scaling of the $\mathrm{Rb} / \mathrm{Sr}$ scale.

al., 2007; Johnson et al., 2011; Cartapanis et al., 2013). In the Pleistocene section of the Lake El'gygytgyn record, the $\mathrm{Si}_{\mathrm{mc}} / \mathrm{Ti}$ (in the following mentioned simply as $\mathrm{Si} / \mathrm{Ti}$ ) ratio exhibits systematic fluctuations in amplitude with lows between 0.2 and 0.4 during cold stages, moderate values between 0.4 and 0.8 during interstadials and normal interglacials, and peaks exceeding 0.8 during peak interglacials (e.g., MIS 11.3, MIS 31, MIS 87; Figs. 3, 4). The absolute $\mathrm{Si} / \mathrm{Ti}$ maximum of 1.92 occurs during MIS 11.3 at $404.5 \mathrm{ka}$. 


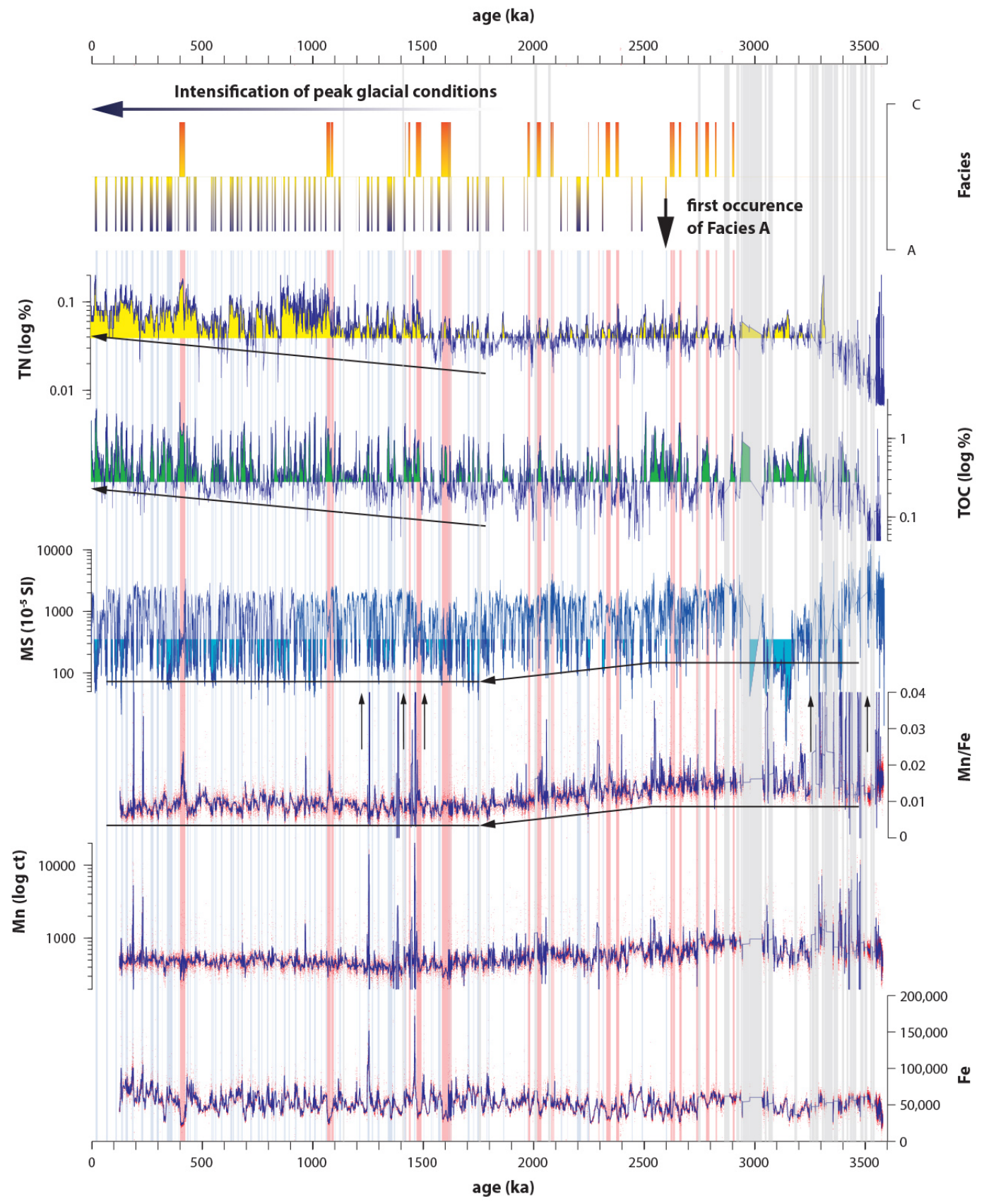

Figure 5. XRF scanning Fe and Mn intensities and Mn / Fe ratios as well magnetic susceptibility (MS; Nowaczyk et al., 2013), total organic carbon (TOC), total nitrogen (TN) contents, and the occurrence of sediment facies A and C in the sediment record from Lake El'gygytgyn vs. age. XRF data are plotted as raw data (blue dots) and 101-point weighted running average (colored lines). Magnetic susceptibility data are smoothed by 500-year weighted running mean to improve the signal-to-noise ratio. Blue and red bars mark the occurrence of sediment facies A and C. Gaps in the record are shaded with grey bars. Please not the logarithmic scaling of the Mn, TN, TOC, and MS scales. Vertical arrows in the $\mathrm{Mn} / \mathrm{Fe}$ record mark values beyond 0.4 that were cropped due to displaying reasons.

The $\mathrm{Si} / \mathrm{Ti}$ ratio has been shown to strongly correlate with the $\mathrm{BSi}$ content $\left(R^{2}=0.88\right)$, thus confirming $\mathrm{Si} / \mathrm{Ti}$ to be primarily modulated by variations in the primary production of the lake (Melles et al., 2012). The pronounced variability of aquatic primary production on glacial-interglacial timescales is controlled by both orbitally induced changes in climate through its influence on the ice cover of the lake and also by long-term changes in the intensity of weathering in the catchment as a trigger of nutrient flux into the lake. 
$\mathrm{Si} / \mathrm{Ti}$ and $\mathrm{Si}_{\mathrm{mc}}$ exhibit a clear minimum in the early lake stage prior to $3.2 \mathrm{Ma}$, although the $\mathrm{BSi}$ accumulation rate reaches the highest values in the entire record (Meyer-Jacob et al., 2014). A 10-fold-higher sedimentation rate during this interval (Nowaczyk et al., 2013; Fig. 3) points to dilution of the primary BSi content by an enhanced flux of Si-depleted but Ti-enriched clastic material, which, in turn, can be traced back to increased precipitation, steeper relief of the young crater, and reduced or absent permafrost within the catchment (Sauerbrey et al., 2013; Brigham-Grette et al., 2013).

\subsubsection{Mn and Fe}

Although chemically very similar, iron and manganese exhibit different distribution patterns in the sediments of Lake El'gygytgyn (Fig. 5). Mn intensities are relatively constant throughout the record, with an average of $693 \mathrm{ct}$, but pronounced maxima (exceeding $1000 \mathrm{ct}$ ) during some glacial periods. Fe intensities, in contrast, are characterized by much stronger amplitude changes on glacial to interglacial timescales, with higher values of usually up to ca. $80000 \mathrm{ct}$ during cold stages and lows down to 20000 ct during warmer periods (Figs. 4, 5). Thus, Fe behaves very similarly to typical detrital elements, like $\mathrm{Ti}$ or $\mathrm{K}$, as also demonstrated by a positive $\mathrm{TiO}_{2}-\mathrm{Fe}_{2} \mathrm{O}_{3}$ correlation in the upper $440 \mathrm{kyr}$ of the El'gygytgyn record (Minyuk et al., 2014) and similar distribution of $\mathrm{Ti}$ and $\mathrm{Fe}$ in surface sediments of the lake (Wennrich et al., 2013). Extraordinary low Fe intensities during MIS 11.3 (Fig. 4) are interpreted as a consequence of particularly pronounced dilution by biogenic opal. During peak glacials, very pronounced short-term Fe peaks of up to 200000 ct occur synchronously with lows in MS (Figs. 4, 5 ), indicating the formation of nonferromagnetic mineral phases. In aquatic environments both $\mathrm{Fe}$ and $\mathrm{Mn}$ have been shown to react sensitively to changes in the redox condition. Although, both $\mathrm{Fe}$ and $\mathrm{Mn}$ have different $\mathrm{E}_{\mathrm{h}}$ stability fields, with Mn exhibiting a higher solubility under less oxic conditions (Davison, 1993). In fully oxygenated surface and downcore sediments of Lake El'gygytgyn, prevailing during interglacial climates, iron occurs in a variety of different phases, including magnetite, titanomagnetite, haematite, chromite, and ilmenite, as well as $\mathrm{Fe}$ (oxyhydr)oxides (Nowaczyk et al., 2002; Wennrich et al., 2013; Minyuk et al., 2014). Under oxic conditions, manganese oxides and hydroxides often co-precipitate with Fe (oxyhydr)oxides (Hongve, 1997), and thus are assumed to account for a majority of the Mn. The $\mathrm{Mn} / \mathrm{Fe}$ ratio as proxy for syn- and postdepositional redox conditions in the bottom waters and sediment in lacustrine systems (e.g., Koinig et al., 2003; Naeher et al., 2013) usually has higher values between 0.01 and 0.03 in oxic sediments of Lake El'gygytgyn (Figs. 4, 5).

During full glacial periods with reducing bottom- and pore-water conditions as a result of a perennial ice cover (Melles et al., 2007, 2011, 2012), magnetite is widely dissolved. Under such conditions, chlorite and biotite are the major Fe-bearing minerals (Minyuk et al., 2014), as is evident in the high correlation of $\mathrm{Fe}$ with the fine silt $(R=0.59)$ and very fine silt fraction $(R=0.52$; Table 1$)$. Furthermore, anoxia promotes the additional diagenetic formation of abundant vivianite and, to a lesser extent, siderite (Murdock et al., 2013; Minyuk et al., 2013). Under these $\mathrm{E}_{h}$ and $\mathrm{pH}$ conditions, the increased solubility of Mn compared to Fe under anoxic conditions presumably prohibited the ability of $\mathrm{Mn}$ to form stable minerals, thus, causing typically lower $\mathrm{Mn} / \mathrm{Fe}$ ratios in the peak glacial sediments of facies A (Fig. 4). Coinciding peaks of $\mathrm{Mn}$ and the $\mathrm{Mn} / \mathrm{Fe}$ ratio (up to 0.2 and above) during single peak glacial phases at 1460, 1382, 1255, 965, 230, and 187 ka (Figs. 4, 5) point to exceptional Mn enrichment. Supported by synchronous peaks in TIC (cf. Fig. 3), this enrichment likely is due to the formation of rhodochrosite $\left(\mathrm{MnCO}_{3}\right)$. Although the $\mathrm{MnCO}_{3}$ formation is linked to anoxia in general (Frederichs et al., 2003; Murdock et al., 2013), its occurrence is presumably limited to periods of slightly higher $\mathrm{E}_{h}$ values compared to vivianite and/or higher pH values (e.g., Koinig et al., 2003), as well as the availability of carbonate ions in the pore waters. The latter is primarily controlled by the decay of organic matter in the sediments of Lake El'gygytgyn, which can be mainly excluded for the full anoxic condition as reconstructed for facies A (Melles et al., 2007). This explains the occurrence of the rhodochrosite just at the transition to full glacial conditions (e.g., see peaks at 187 and $230 \mathrm{ka}$ in Fig. 4).

The short-term variability in the amplitudes of the $\mathrm{Mn} / \mathrm{Fe}$ signal of Lake El'gygytgyn is overprinted by long-term gradual $\mathrm{Mn} / \mathrm{Fe}$ decrease from a higher level between ca. 3.6 and 2.3 Ma to a steady state that was reached ca. 1.8 Ma (Fig. 5). This indicates a gradual trend to less oxic conditions at the lake bottom, likely caused by a progressive change in the lake hydrology with a gradual drop in the bottom-water oxygenation. A lower bottom-water oxygenation is also confirmed by a simultaneous baseline reduction in the MS and a shift toward higher TOC and TN contents (Fig. 5), presumably due to a reduction of organic matter mineralization.

\subsubsection{Rb and $\mathrm{Sr}$}

Rubidium and strontium as trace elements abundantly occur in the sediments of Lake El'gygytgyn. The XRF scanner analyses yield mean $\mathrm{Rb}$ and $\mathrm{Sr}$ counts from 176 to 548 and 177 to 1417, respectively (Fig. 6). Modern surface sediments of the lake are characterized by $\mathrm{Sr}$ contents between ca. 51 and $116 \mathrm{ppm}$ (Wennrich et al., 2013). In the upper part of the sediment record between ca. 440 and $125 \mathrm{ka}, \mathrm{Rb}$ and $\mathrm{Sr}$ concentrations are up to 154 and 249 ppm, respectively (Minyuk et al., 2014).

In Lake El'gygytgyn sediments $\mathrm{Sr}$ is mainly associated with the occurrence of Na-Ca-feldspars and K-feldspars from the surrounding acidic and andesitic volcanic rocks (Wennrich et al., 2013) substituting for sodium, calcium, or potassium (El Bouseily and El Sokkary, 1975; Cherniak and 


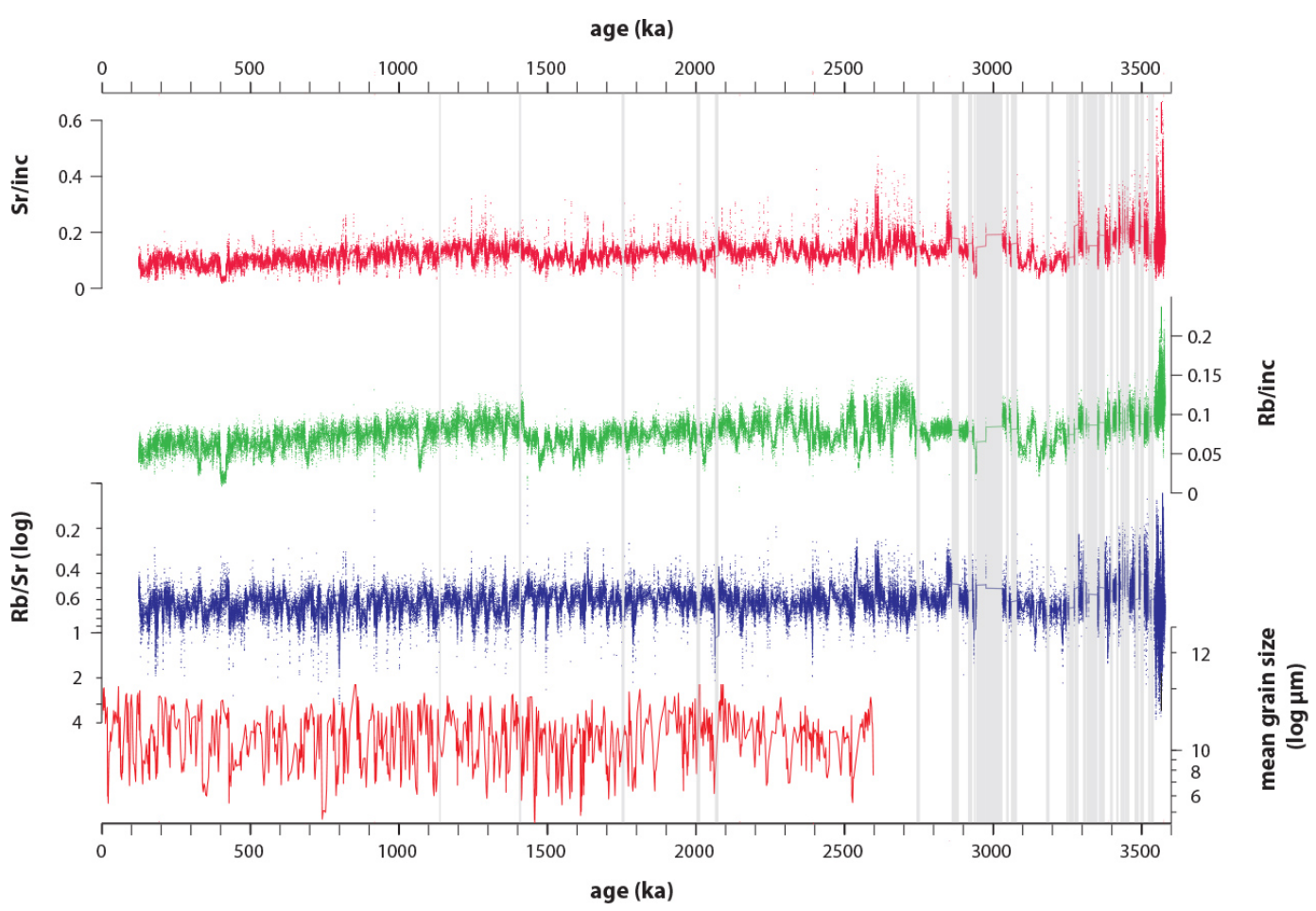

Figure 6. Mean grain size (from Francke et al., 2013), incoherent scatter normalized $\mathrm{Rb}(\mathrm{Rb} / \mathrm{inc}$ ) and $\mathrm{Sr}$ intensities ( $\mathrm{Sr} / \mathrm{inc})$, and $\mathrm{Rb} / \mathrm{Sr}$ ratios derived by XRF scanning in the sediment record from Lake El'gygytgyn vs. age. XRF data are plotted as raw data (dots) and 101-point ( $\mathrm{Sr} ; \mathrm{Rb} / \mathrm{Sr}$ ) or 201-point weighted running average (colored lines). Gaps in the record are shaded with grey bars. Please not the reverse scaling of the $\mathrm{Rb} / \mathrm{Sr}$ ratio curve.

Watson, 1994). Due to its similar ionic radius, $\mathrm{Rb}$, in contrast, preferentially replaces K (Chang et al., 2013), and thus is commonly found in K-feldspars as well as mica and clay minerals (Kylander et al., 2011; Fralick and Kronberg, 1997). Hence, $\mathrm{Rb}$ is typically enriched in the fine-grained sediment fraction of weathering products of silicates (Koenig et al., 2011; Dypvik and Harris, 2001).

The resulting $\mathrm{Rb} / \mathrm{Sr}$ ratio of the XRF scanner measurements shows highly variable values with mean values varying between 0.12 and 2.60 (Fig. 6). In general, higher values occur during glacial periods and lows during interglacial periods, thus supporting the previously stated climate dependency of the $\mathrm{Rb} / \mathrm{Sr}$ ratio in the mid- to late Pleistocene section of the Lake El'gygytgyn core (Minyuk et al., 2011, 2014).

The $\mathrm{Rb} / \mathrm{Sr}$ (or $\mathrm{Sr} / \mathrm{Rb}$ ) ratio is commonly used as an indicator of the weathering intensity of the bedrock in different kinds of sediments records (e.g., Chang et al., 2013; Jin et al., 2001; Dasch, 1969; Heymann et al., 2013), but has also been interpreted in terms of grain-size variations of Siberian lakes Teletskoye and El'gene-Kyuele (Kalugin et al., 2007; Biskaborn et al., 2013). Previous studies of Lake El'gygytgyn sediments on interglacial/glacial timescales attributed variations in the $\mathrm{Rb} / \mathrm{Sr}$ ratio mainly to an enhanced Sr depletion due to higher chemical alteration, which in turn is controlled by grain size (Minyuk et al., 2011, 2014). The comparison of our high-resolution $\mathrm{Rb} / \mathrm{Sr}$ data with grain-size data determined on sediments from ICDP Site 5011-1 (Francke et al., 2013) yields a moderate to good anticorrelation of $\mathrm{Rb} / \mathrm{Sr}$ to the mean grain-size $(R=-0.64$; Table 1$)$ with a high correlation to fine and a high anticorrelation to coarse grainsize classes (Table 1), thus strongly supporting the grainsize dependency. The climate-driven grain-size variation in Lake El'gygytgyn is thought to be triggered by the occurrence and absence of a wind-driven current system during interglacials and glacials, respectively, that is hypothesized to deliver coarser material to the lake center (Francke et al., 2013; Wennrich et al., 2013). Thus, variations in the $\mathrm{Rb} / \mathrm{Sr}$ on a longer timescale presumably mirror changes in the inferred circulation of Lake El'gygytgyn, which is interpreted to be mainly controlled by the presence/absence of a perennial ice cover at the lake (Asikainen et al., 2007; Francke et al., 2013). Furthermore, the $\mathrm{Rb} / \mathrm{Sr}$ signal exhibits an obvious cyclicity over the past $3.6 \mathrm{Myr}$ with a dominance of the $41 \mathrm{kyr}$ obliquity band for the interval prior to ca. $0.63 \mathrm{Ma}$ and the $100 \mathrm{kyr}$ eccentricity band for sediments younger than ca. $0.63 \mathrm{Myr}$ (Fig. 7). The $21 \mathrm{kyr}$ precession band plays only a minor role in the $\mathrm{Rb} / \mathrm{Sr}$ data. 

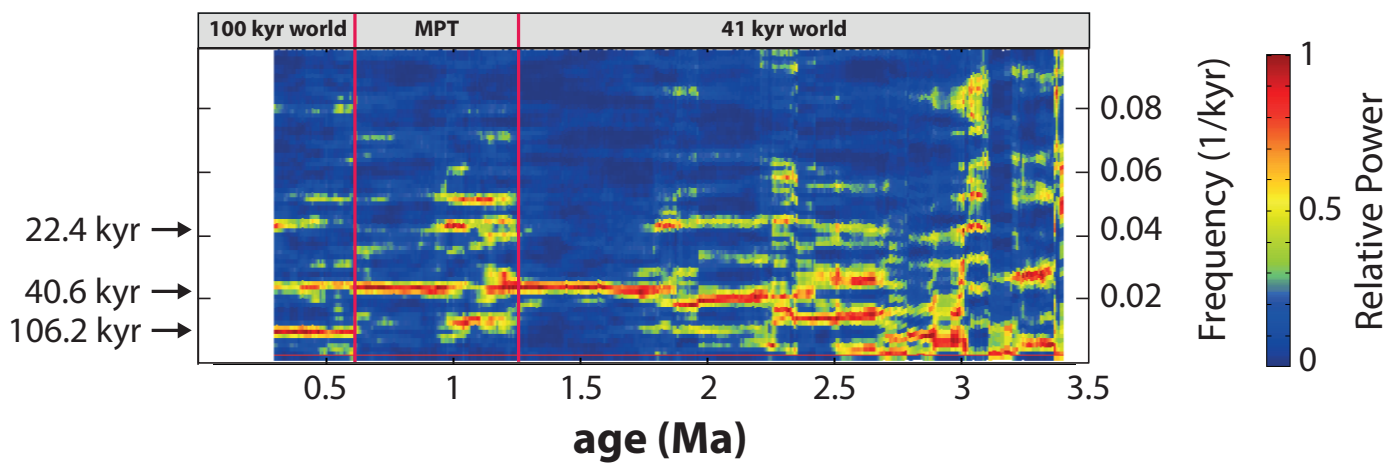

Figure 7. Evolutionary power spectrum of the Rb / Sr ratios from 305 to $3397 \mathrm{ka}$, resulting from the chosen window width of $240 \mathrm{ka}$ (window type: boxcar). The software used, ESALAB (Weber et al., 2010), is based on the same algorithms as REDFIT38.

\section{Long-term climate history}

The elemental composition of the lacustrine sediment record of Lake El'gygytgyn has proven to be influenced by the flux of detrital material into the lake, by the sediment transport within the water column, as well as by lake-internal processes, such as the primary diatom production and redox processes at the lake bottom and in the subsurface sediments. Since most of these processes are triggered by local climate variations that are assumed to be consistent with regionaland global-scale changes driven by orbital forcing, highresolution elemental data can be used as suitable proxies to reconstruct the environmental and climatic history of Lake El'gygytgyn and its catchment of the past 3.6 Myr.

\subsection{Mid- to late Pliocene (3.6-2.8 Ma)}

The early history of Lake El'gygytgyn is characterized by a high flux of clastic material into the lake as visible in elevated $\mathrm{K}$ values during the first approximately 10000 years after the lake formation at ca. $3.58 \mathrm{Ma}$, and in the 10 -fold-higher sedimentation rate until 3.3 Ma (Nowaczyk et al., 2013; Fig. 3). Higher sediment flux from the catchment is assumed to be the result of the steeper relief of the young crater (Sauerbrey et al., 2013), intensified by a higher annual precipitation of ca. $600 \mathrm{~mm} \mathrm{yr}^{-1}$ and the absence of permafrost in the catchment (Brigham-Grette et al., 2013; Tarasov et al., 2013), but might be additionally amplified by sediment focusing in the bowl-shaped basin. Greater seasonal in-lake productivity during the mid-Pliocene warmth as evoked by higher BSi accumulation rates and larger diatom frustules (Brigham-Grette et al., 2013; Meyer-Jacob et al., 2014) is neither noticeable in the $\mathrm{Si}$ / Ti ratios nor in the TOC contents (Figs. 3, 5), as these signals are strongly influenced by dilution with Si-depleted but Ti-enriched detrital material. Higher $\mathrm{Mn} / \mathrm{Fe}$ ratios during this period suggest well-oxygenated bottom-water conditions, thus pointing to a shortened seasonal lake ice cover. Calcite formation and/or deposition in the basal part of the core as indicated by simultaneously intensified $\mathrm{Ca}$ and TIC contents (Fig. 3) required an oversaturation of bottom or pore waters with both $\mathrm{Ca}^{2+}$ and $\mathrm{CO}_{3}^{2-}$ ions, which is excluded for modern Lake El'gygytgyn waters characterized by low cation and anion concentrations (Cremer et al., 2005). Thus, the calcite formation can presumably be traced back to an enhanced ion (and nutrient) flux into the lake due to intensified chemical weathering in the lake catchment. This would have been promoted by a $7-8^{\circ} \mathrm{C}$ warmer and ca. $400 \mathrm{~mm}$ wetter regional climate and reduced or absent permafrost during the mid-Pliocene as postulated by Brigham-Grette et al. (2013). Furthermore, the higher degree of chemical weathering might be linked to an ongoing hydrothermal activity in the young crater. In the Ries crater (Germany), a crater of comparable size to the El'gygytgyn crater, recent studies have implied the hydrothermal activity to have proceeded several 100000 s of years after the impact (Arp et al., 2013).

Decreasing $\mathrm{Ca}$ and TIC values at ca. 3.25 Ma (Fig. 3) slightly postdate the most remarkable cooling of the midPliocene at Lake El'gygytgyn during isotope stage M2 (3.312-3.264 Ma; Lisiecki and Raymo, 2005), when both marine and terrestrial records - e.g., from the North Atlantic, Lake Baikal, and the Ross Sea - strongly imply a global cooling (Demske et al., 2002; Naish et al., 2009; Lawrence et al., 2009; De Schepper et al., 2009). In the pollen record of Lake El'gygytgyn, the M2 cold event is visible in a dramatic change to cold-adapted trees around the lake (Andreev et al., 2013) that has been hypothesized to be linked to permafrost onset during the so-called Mammoth subchrone at ca. 3.3 Ma (Brigham-Grette et al., 2013). Given a postdepositional origin of the calcite in the lower core section, the drop of calcite after the M2 event indicates a change in the bottomand/or pore-water conditions at the sediment-water interface of Lake El'gygytgyn. A persistent enhanced organic matter decay after 3.2 Ma, and thus $\mathrm{CO}_{2}$ release at the lake bottom as interpreted from an elevated TOC accumulation after M2 (Meyer-Jacobs et al., 2014), as well as the formation of rhodochrosite in the later record (Murdock et al., 2013) suggest at least the temporary saturation of $\mathrm{CO}_{3}^{2-}$ in the bottom 
sediments. Hence, $\mathrm{Ca}^{2+}$ seems to be the limiting factor for calcite formation, and thus the drop in calcite points to a reduction of the $\mathrm{Ca}^{2+}$ flux into the lake. This decreased $\mathrm{Ca}$ flux likely can be traced back to a slowdown in chemical weathering in the catchment, presumably due to initial permafrost formation and/or termination of the hydrothermal activity in the crater. Simultaneously, decreasing sedimentation rates (Fig. 3) as well as a reduced mass movement frequency and turbidite thickness after 3.3 Ma (Sauerbrey et al., 2013) further imply a drop in the sediment flux into the lake, which in turn might be linked to a certain crater slope stabilization in the catchment.

High lake productivity due to a protracted warmer and moist climate until after 3.0 Ma (Brigham-Grette et al., 2013) is clearly evident in high $\mathrm{Si} / \mathrm{Ti}$ and TOC values (Figs. 3, 5). The high diatom production as also indicated by high BSi accumulation rates (Brigham-Grette et al., 2013; Meyer-Jacobs et al., 2014) strongly dilute the clastic sediment content resulting in lows of all clastic-related elements, like $\mathrm{K}, \mathrm{Ca}$, and $\mathrm{Ti}$ (Fig. 3). A gradual lowering of the $\mathrm{Si} / \mathrm{Ti}$ ratio and a contemporaneous increase in clastic elements after the MIS KM2 (3.15-3.119 Ma; Lisiecki and Raymo, 2005) until ca. 3.0 Ma indicate a deterioration of the in-lake bioproduction and induce a transitional period to Pleistocene-style variations of in-lake processes. This shift predates a stepwise cooling in summer temperatures as reconstructed from pollen data at ca. 3.02 Ma (Brigham-Grette et al., 2013) but coincides with a shift to more open landscapes after MIS KM2 (Tarasov et al., 2013) and a drop in winter temperatures after 3.25 Ma (Brigham-Grette et al., 2013).

\subsection{Plio-Pleistocene transition (2.8-1.5 Ma)}

After the mid-Pliocene warmth, the interval between 2.8 and 1.5 Ma marks a transitional phase from relatively uniform Pliocene conditions to the high-amplitude variability of the Pleistocene. The most striking feature in the element data of this interval is the onset of a pronounced glacial-to-interglacial cyclicity visible in most geochemical proxies, i.e. for clastic input, grain-size distribution, redoxconditions, or primary production at ca. $2.67 \mathrm{Ma}$, thus displaying an overall change not only in the lake but also in its catchment. This change to higher-amplitude variations just slightly postdates a drop in precipitation and winter temperatures at $2.73 \mathrm{Ma}$ reconstructed from pollen data (BrighamGrette et al., 2013; Tarasov et al., 2013; Andreev et al., 2013), and the onset of subarctic Northern Pacific stratification interpreted to have triggered an intensified Northern Hemisphere glaciation (e.g., Haug et al., 2005).

The regular glacial-interglacial variability is interrupted by periods of exceptionally elevated diatom production as visible in $\mathrm{Si} / \mathrm{Ti}$ ratios $>0.8$ and the occurrence of sediment facies C during MIS 93, 91, 87, 77, and 55 at ca. 2.38, 2.34, 2.26, 2.03, and 1.60 Ma, respectively (Fig. 3). Based on unusually high $\mathrm{BSi}$ concentrations and pollen spectra as well as the exceptional occurrence of facies $\mathrm{C}$ in the Lake El'gygytgyn record, these periods have previously been defined as "super-interglacials" (Melles et al., 2012). The super-interglacials mark periods of unusual Arctic warming at Lake El'gygytgyn that are widely synchronous to major retreats in the West Antarctic Ice Sheet as interpreted from Ross Sea sediments (Melles et al., 2012; Naish et al., 2009). Extreme peaks in the BSi content of the sediments and BSi accumulation rate (Meyer-Jacob et al., 2014) are thought to have strongly diluted the clastic contents (Minyuk et al., 2014) causing the majority of proxies related to detrital clastic input into the lake - like $\mathrm{Ti}, \mathrm{K}, \mathrm{Rb}$, and $\mathrm{Ca}$ - to have minima (Figs. 3, 4, 6). Furthermore, a denser vegetation cover reconstructed for the super-interglacials (Melles et al., 2012; Andreev et al., 2013) in combination with a presumably reduced permafrost activity in the lake catchment might have buffered the detrital influx into the lake.

During MIS 104 (2.602-2.598 Ma) typical finely laminated silt and clay of facies A for the first time occur in the sediment sequence of Lake El'gygytgyn (Melles et al., 2012; Fig. 5). Facies A sediments are linked to sedimentation processes under a perennial ice cover (Melles et al., 2007; Melles et al., 2011), implying that during MIS 104 for the first time mean annual temperatures at the lake fell below a critical threshold of $5.5 \pm 1.0^{\circ} \mathrm{C}$ below modern that is required to initiate multiyear lake ice and to eliminate oxygen exchange with the atmosphere (Nolan, 2013). This is clearly confirmed by results of pollen analyses yielding a substantial cooling in the surrounding of Lake El'gygytgyn during this interval (Melles et al., 2012; Andreev et al., 2013) that is also seen in the Lake Baikal record (Demske et al., 2002). Low $\mathrm{Mn} / \mathrm{Fe}$ ratios and MS as well as high TOC contents during periods of facies A sedimentation (Fig. 5) clearly point to anoxia at the lake bottom with reduced organic burial, magnetite dissolution, and the formation of vivianite and rhodochrosite (Nowaczyk et al., 2002; Murdock et al., 2013; Minyuk et al., 2013). Low $\mathrm{Si} / \mathrm{Ti}$ in combination with high $\mathrm{Ti}, \mathrm{K}$, and $\mathrm{Rb} / \mathrm{Sr}$ (Figs. 3, 6) further indicate a diminished primary production under the perennial lake ice, and thus clastic-dominated fine-grained sediments during these peak glacial periods.

The progressive appearance of facies $\mathrm{A}$ in the Lake El'gygytgyn sediments after ca. $2.3 \mathrm{Ma}$ until ca. $1.8 \mathrm{Ma}$, accompanied by a gradual baseline-level drop of $\mathrm{Mn} / \mathrm{Fe}$ and MS and a rise in TOC and TN (Fig. 5), suggest an overall change in the lake hydrology and a reduced level of bottomwater oxygenation likely due to a higher frequency of pervasive glacial episodes (Melles et al., 2012). The termination of this gradual trend at ca. $1.8 \mathrm{Ma}$ as indicated by knick points in both the $\mathrm{Mn} / \mathrm{Fe}$ and MS record (Fig. 5) is interpreted as marking the full establishment of glacial-interglacial cycles in the lake region (Melles et al., 2012), which coincides with a period of accelerated glacial erosion in British Columbia (Shuster et al., 2005). Furthermore, the timing also coincides with major changes in the paleoceanography of the 
adjacent marine realm. The central Bering Sea simultaneously experienced a major drop in opal accumulation but an increase in MS at $1.8 \mathrm{Ma}$ that is interpreted as a result of a change in ocean circulation (März et al., 2013). A decrease in temperate-water species and an increase in sea-ice indicators in the diatom assemblages at the Bering slope point to major cooling and a sea-ice expansion during this interval (Teraishi et al., 2013). In the subarctic North Pacific the onset of a major subpolar cooling at ca. $1.8 \mathrm{Ma}$ induced a temperature drop of $4-5^{\circ} \mathrm{C}$ until $1.2 \mathrm{Ma}$ (Martínez-Garcia et al., 2010). This cooling might have caused both a cooling of the western Beringian landmass and an increase in continentality on the Chukchi Peninsula due to a reduced moisture transport capacity of the colder air.

\subsection{Pleistocene climate variability}

The elemental composition of the Pleistocene section of the Lake El'gygytgyn record is marked by a notable cyclicity especially in $\mathrm{Ti}$ and $\mathrm{Fe}$, but also the $\mathrm{Rb} / \mathrm{Sr}$ and $\mathrm{Si} / \mathrm{Ti}$ signals (Figs. 3, 4, 6), whose correspondence to variations in the benthic marine isotope stack LR04 (Lisiecki and Raymo, 2005; Figs. 3,4 ) clearly demonstrates a link to orbitally driven climate change. The apparent shift in the frequency of glacialinterglacial variability between ca. 1.2 and 0.6 Ma that is visible especially in the $\mathrm{Rb} / \mathrm{Sr}$ ratio and in the mean grain size (Francke et al., 2013; Figs. 6, 7) might therefore correspond to the change from a $41 \mathrm{kyr}$ obliquity to $100 \mathrm{kyr}$ eccentricity dominance in the glacial-interglacial frequency during the middle Pleistocene transition (MPT; Clark et al., 2006). This and the correspondence of the $\mathrm{Si} / \mathrm{Ti}$ ratio to the isotope stack (Figs. 3, 4) clearly indicate that internal lake processes and processes in the catchment that act as indirect indicators of the local climate at Lake El'gygytgyn are linked to global changes driven by orbital forcing (Nowaczyk et al., 2013).

Beyond the glacial-interglacial variability, the gradually increasing TOC and TN contents in combination with a higher frequency in the occurrence of facies A during the past 1.5-1.6 Myr, and especially after 1.1 Ma (Fig. 5), strongly imply a gradual trend to a longer and/or intensified ice coverage during peak glacial periods. Prolonged anoxic conditions under a perennial ice cover presumably prohibited the organic matter mineralization, with especially the easily removable nitrogen effectively buried in the sediment. The suggested intensified ice coverage of Lake El'gygytgyn presumably mirrors a prolongation of the peak glacial periods in combination with minimum winter temperatures that persistently dropped below the critical threshold of $5.5^{\circ}$ lower than today (Nolan, 2013), likely as a result of larger variations in the glacial-interglacial temperature amplitudes.

Similar to the early Pleistocene super-interglacials, three periods of extraordinary high $\mathrm{Si} / \mathrm{Ti}$ ratios accompanied by low detrital clastic parameters during MIS 49, 31, and 11.3 at ca. $1.48,1.07$, and $0.40 \mathrm{Ma}$, respectively, clearly exceed the range of normal glacial-interglacial cyclicity (Figs. 3,
4). Pollen-based climate reconstructions identified MIS 31 and MIS 11.3 as the warmest and wettest of all superinterglacials, with maximum summer temperatures and annual precipitation of $4-5^{\circ} \mathrm{C}$ and ca. $300 \mathrm{~mm}$ higher even than during the Holocene thermal maximum (Melles et al., 2012). Warmer climate and an associated higher nutrient flux from the catchment into the lake during both MIS 31 and MIS 11.3 (Snyder et al., 2013; Vogel et al., 2013), in combination with a reduced ice coverage, promoted a maximum in-lake productivity as indicated by the peaks not only in $\mathrm{Si} / \mathrm{Ti}$ but also in BSi as well as the diatom concentration and diversity (Snyder et al., 2013; Vogel et al., 2013). Higher nutrient flux was presumably supported by an enhanced soil formation due to a dense vegetation cover dominated by boreal evergreen conifer and cool-temperate broadleaf forests (Tarasov et al., 2013; Vogel et al., 2013). The elevated Mn/Fe ratio during the super-interglacials and simultaneous lows in clastic-bound elements indicates that the reduced MS during these periods (Figs. 4, 5) was mainly driven by dilution with high biogenic components (Nowaczyk et al., 2013) rather than by magnetite dissolution as derived for the full glacial lows (Nowaczyk et al., 2002, 2007).

\section{Conclusions}

High-resolution inorganic elemental analyses by XRF core scanning have been conducted on the complete $318 \mathrm{~m}$ long lacustrine sediment sequence of Lake El'gygytgyn/Far East Russian Arctic. The results shed new light on the regional climate and environmental evolution since the mid-Pliocene formation of the lake $3.58 \mathrm{Ma}$ as indicated by changes in lake productivity, postsedimentary diagenetic processes, and current activity in the lake as well as weathering processes in its catchment.

1. Fluctuations in titanium, potassium, and calcium indicate major changes in the detrital clastic content of the sediment that are driven by glacial-interglacial variations in the weathering intensity in the lake's surrounding and the clastic supply to the lake center, but also by dilution by biogenic opal. Calcium enrichment in the mid-Pliocene section can be traced back to calcite formation in the early lake history. The lack of calcite formation after ca. 3.3 Ma is associated with a drop in the $\mathrm{Ca}$ flux into the lake due to permafrost onset during the M2 cooling event that might be linked to the termination of hydrothermal activity in the catchment after the impact.

2. Besides detrital sources, silicon in Lake El'gygytgyn sediments is mainly derived from diatom production in the water column. A strong interglacial/glacial variability in the $\mathrm{Si} / \mathrm{Ti}$ ratio as proxy of the biogenic opal content is caused by climate-driven changes in the lake productivity due to a variable seasonal ice coverage of 
the lake and the nutrient flux from the catchment. Extreme $\mathrm{Si} / \mathrm{Ti}$ maxima during eight Pleistocene superinterglacials reflect periods of an exceptional warming.

3. Manganese and iron signals in the sediment record are strongly modulated by redox-dependent diagenetic alteration processes in the bottom-water and subsurface sediments. The redox-sensitive $\mathrm{Mn} / \mathrm{Fe}$ ratio exhibits a drop in the baseline level between 2.3 and $1.8 \mathrm{Ma}$ due to changes in lake hydrology that are presumably caused by an intensified cooling during peak glacial intervals linked to modifications of the paleoceanographic setting in the North Pacific and the Bering Sea.

4. The rubidium-to-strontium ratio of the Lake El'gygytgyn sediments strongly correlates with their grain-size distribution. Changes in the $\mathrm{Rb} / \mathrm{Sr}$ cyclicity between ca. 1.2 and $0.6 \mathrm{Ma}$ are thought to have been triggered by a shift in the glacial-interglacial frequency from the $41 \mathrm{kyr}$ obliquity band to a $100 \mathrm{kyr}$ eccentricity dominance during the middle Pleistocene transition.

\section{The Supplement related to this article is available online at doi:10.5194/cp-10-1381-2014-supplement.}

Acknowledgements. We want to thank all participants of the International "El'gygytgyn Drilling Project" in 2008/2009 for recovering the unique record of Lake El'gygytgyn, additional support, and collaborations. The drilling campaign was funded by the International Continental Scientific Drilling Program (ICDP), the US National Science Foundation (NSF; grants OPP 007122, 96-15768, and 0002643), the German Federal Ministry of Education and Research (BMBF; grant 03G0642), Alfred Wegener Institute (AWI) and GeoForschungsZentrum Potsdam (GFZ), the Russian Academy of Sciences Far East Branch (RAS FEB), the Russian Foundation for Basic Research (RFBR), and the Austrian Federal Ministry of Science and Research (BMWF). The Russian GLAD 800 drilling system was developed and operated by DOSECC Inc., and LacCore, at the University of Minnesota, handled core curation. This study was financially supported by the German Federal Ministry for Education and Research (BMBF, grant no. 03G0642A) and was partly funded by RFBR (12-05-00286). Furthermore, we are grateful to Nicole Mantke, Armine Shahnazarian, and numerous students for their technical assistance and conducting the initial core processing and XRF scanning in the laboratory at the University of Cologne.

Edited by: T. Cook

\section{References}

Andreev, A. A., Tarasov, P. E., Wennrich, V., Raschke, E., Herzschuh, U., Nowaczyk, N. R., Brigham-Grette, J., and Melles, M.: Late Pliocene and early Pleistocene environments of the north-eastern Russian Arctic inferred from the Lake El'gygytgyn pollen record, Clim. Past Discuss., 9, 4599-4653, doi:10.5194/cpd-9-4599-2013, 2013.

Arp, G., Kolepka, C., Simon, K., Karius, V., Nolte, N., and Hansen, B. T.: New evidence for persistent impact-generated hydrothermal activity in the Miocene Ries impact structure, Germany, Meteor. Planet. Sci., 48, 2491-2516, 2013.

Asikainen, C. A., Francus, P., and Brigham-Grette, J.: Sedimentology, clay mineralogy and grain-size as indicators of $65 \mathrm{ka}$ of climate change from El'gygytgyn Crater Lake, Northeastern Siberia, J. Paleolimnol., 37, 105-122, 2007.

Barr, I. D. and Clark, C. D.: Glaciers and climate in Pacific Far NE Russia during the Last Glacial Maximum, J. Quat. Sci., 26, $227-$ 237, 2011.

Belyi, V.: Impactite generation in the El'gygytgyn depression, northeast Russia, as a volcanic phenomenon, 2. On the petrography and geochemistry of the impactites, J. Volcanol. Seismol., 4, 149-163, 2010.

Belyi, V. and Raikevich, M. I.: The El'gygytgyn lake basin (geological structure, morphostructure, impactites, problems of investigation and preservation of nature), NEISRI FEB RAS, Magadan, 27 pp., 1994.

Biskaborn, B. K., Herzschuh, U., Bolshiyanov, D. Y., Schwamborn, G., and Diekmann, B.: Thermokarst Processes and Depositional Events in a Tundra Lake, Northeastern Siberia, Permafr. Perigl. Proc., 24, 160-174, doi:10.1002/ppp.1769, 2013.

Bogaard, C. v. d., Froese, D., Jensen, B., Pearce, N., Ponomareva, V., Portnyagin, M., and Wennrich, V.: Volcanic Ash Layers in Lake El'gygytgyn Sediments, Far East Russian Arctic, Clim. Past, in preparation, 2014.

Brigham-Grette, J., Melles, M., Minyuk, P., and Scientific Party: Overview and significance of a 250 ka paleoclimate record from El'gygytgyn Crater Lake, NE Russia, J. Paleolimnol., 37, 1-16, 2007.

Brigham-Grette, J., Melles, M., Minyuk, P., Andreev, A., Tarasov, P., DeConto, R., Koenig, S., Nowaczyk, N., Wennrich, V., Rosén, P., Haltia, E., Cook, T., Gebhardt, C., Meyer-Jacob, C., Snyder, J., and Herzschuh, U.: Pliocene Warmth, Polar Amplification, and Stepped Pleistocene Cooling Recorded in NE Arctic Russia, Science, 340, 1421-1427, 2013.

Brown, E. T.: Lake Malawi's response to "megadrought" terminations: Sedimentary records of flooding, weathering and erosion, Palaeogeography, Palaeoclimatology, Palaeoecology, 303, 120 125, 2011.

Brown, E. T., Johnson, T. C., Scholz, C. A., Cohen, A. S., and King, J. W.: Abrupt change in tropical African climate linked to the bipolar seesaw over the past 55,000 years, Geophys. Res. Lett., 34, L20702, doi:10.1029/2007g1031240, 2007.

Cartapanis, O., Tachikawa, K., Romero, O. E., and Bard, E.: Persistent millennial-scale link between Greenland climate and northern Pacific Oxygen Minimum Zone under interglacial conditions, Clim. Past, 10, 405-418, doi:10.5194/cp-10-405-2014, 2014.

Chang, H., An, Z., Wu, F., Jin, Z., Liu, W., and Song, Y.: A Rb/Sr record of the weathering response to environmental changes in westerly winds across the Tarim Basin in the late Miocene 
to the early Pleistocene, Palaeogeogr. Palaeocl., 386, 364-373, doi:10.1016/j.palaeo.2013.06.006, 2013.

Cherniak, D. J. and Watson, E. B.: A study of strontium diffusion in plagioclase using Rutherford backscattering spectroscopy, Geochim. Cosmochim. Ac., 58, 5179-5190, 1994.

Clark, P. U., Archer, D., Pollard, D., Blum, J. D., Rial, J. A., Brovkin, V., Mix, A. C., Pisias, N. G., and Roy, M.: The middle Pleistocene transition: characteristics, mechanisms, and implications for long-term changes in atmospheric $p \mathrm{CO}_{2}$, Quat. Sci. Rev., 25, 3150-3184, 2006.

Cremer, H. and Wagner, B.: The diatom flora in the ultraoligotrophic Lake EI'gygytgyn, Chukotka, Polar Biol., 26, 105114, 2003.

Cremer, H., Wagner, B., Juschus, O., and Melles, M.: A microscopical study of diatom phytoplankton in deep crater Lake El'gygytgyn, Northeast Siberia, Alg. Studies, 116, 147-169, 2005.

Croudace, I. W., Rindby, A., and Rothwell, R. G.: ITRAX: description and evaluation of a new multi-function X-ray core scanner, Geol. Soc., 267, 51-63, 2006.

Dasch, E. J.: Strontium isotopes in weathering profiles, deep-sea sediments, and sedimentary rocks, Geochimica et Cosmochimica Acta, 33, 1521-1552,1969.

Davison, W.: Iron and manganese in lakes, Earth-Sci. Rev., 34, 119163, 1993.

Demske, D., Mohr, B., and Oberhänsli, H.: Late Pliocene vegetation and climate of the Lake Baikal region, southern East Siberia, reconstructed from palynological data, Palaeogeogr. Palaeocl. 184, 107-129, 2002.

De Schepper, S., Head, M. J., and Groeneveld, J.: North Atlantic Current variability through marine isotope stage M2 (circa 3.3 Ma) during the mid-Pliocene, Paleoceanography, 24, PA4206, doi:10.1029/2008pa001725, 2009.

Dypvik, H. and Harris, N. B.: Geochemical facies analysis of finegrained siliciclastics using $\mathrm{Th} / \mathrm{U}, \mathrm{Zr} / \mathrm{Rb}$ and $(\mathrm{Zr}+\mathrm{Rb}) / \mathrm{Sr}$ ratios, Chem. Geol., 181, 131-146, 2001.

El Bouseily, A. M. and El Sokkary, A. A.: The relation between Rb, $\mathrm{Ba}$ and $\mathrm{Sr}$ in granitic rocks, Chem. Geol., 16, 207-219, 1975.

Fedorov, G., Nolan, M., Brigham-Grette, J., Bolshiyanov, D., Schwamborn, G., and Juschus, O.: Preliminary estimation of Lake El'gygytgyn water balance and sediment income, Clim. Past, 9, 1455-1465, doi:10.5194/cp-9-1455-2013, 2013.

Fralick, P. W. and Kronberg, B. I.: Geochemical discrimination of clastic sedimentary rock sources, Sediment. Geol., 113, 111124, 1997.

Francke, A., Wennrich, V., Sauerbrey, M., Juschus, O., Melles, M., and Brigham-Grette, J.: Multivariate statistic and time series analyses of grain-size data in quaternary sediments of Lake El'gygytgyn, NE Russia, Clim. Past, 9, 2459-2470, doi:10.5194/cp-9-2459-2013, 2013.

Frank, U., Nowaczyk, N. R., Minyuk, P., Vogel, H., Rosén, P., and Melles, M.: A $350 \mathrm{ka}$ record of climate change from Lake El'gygytgyn, Far East Russian Arctic: refining the pattern of climate modes by means of cluster analysis, Clim. Past, 9, 15591569, doi:10.5194/cp-9-1559-2013, 2013.

Frederichs, T., von Dobeneck, T., Bleil, U., and Dekkers, M. J.: Towards the identification of siderite, rhodochrosite, and vivianite in sediments by their low-temperature magnetic properties, Phys. Chem. Earth, 28, 669-679, 2003.
Gebhardt, A. C., Francke, A., Kück, J., Sauerbrey, M., Niessen, F., Wennrich, V., and Melles, M.: Petrophysical characterization of the lacustrine sediment succession drilled in Lake El'gygytgyn, Far East Russian Arctic, Clim. Past, 9, 1933-1947, doi:10.5194/cp-9-1933-2013, 2013.

Glushkova, O. Y. and Smirnov, V. N.: Pliocene to Holocene geomorphic evolution and paleogeography of the El'gygytgyn Lake region, NE Russia, J. Paleolimnol., 37, 37-47, 2007.

Gurov, E. P., Koeberl, C., Reimold, W. U., Brandstätter, F., and Amare, K.: Shock metamorphism of siliceous volcanic rocks of the El'gygytgyn impact crater (Chukotka, Russia), Geol. Soc. Am. Spec. Papers, 384, 391-391, 2005.

Gurov, E. P., Koeberl, C., and Yamnichenko, A.: El'gygytgyn impact crater, Russia: Structure, tectonics, and morphology, Meteorit. Planet. Sci., 42, 307-319, 2007.

Guyard, H., Chapron, E., St-Onge, G., Anselmetti, F. S., Arnaud, F., Magand, O., Francus, P., and Mélières, M.-A.: High-altitude varve records of abrupt environmental changes and mining activity over the last 4000 years in the Western French Alps (Lake Bramant, Grandes Rousses Massif), Quat. Sci. Rev., 26, 2644 2660, 2007.

Haltia, E. M. and Nowaczyk, N. R.: Magnetostratigraphy of sediments from Lake El'gygytgyn ICDP Site 5011-1: paleomagnetic age constraints for the longest paleoclimate record from the continental Arctic, Clim. Past, 10, 623-642, doi:10.5194/cp-10-6232014, 2014.

Haug, G. H., Hughen, K. A., Sigman, D. M., Peterson, L. C., and Rohl, U.: Southward migration of the intertropical convergence zone through the Holocene, Science, 293, 1304-1308, 2001.

Haug, G. H., Ganopolski, A., Sigman, D. M., Rosell-Mele, A., Swann, G. E. A., Tiedemann, R., Jaccard, S. L., Bollmann, J., Maslin, M. A., Leng, M. J., and Eglinton, G.: North Pacific seasonality and the glaciation of North America 2.7 million years ago, Nature, 433, 821-825, 2005.

Heymann, C., Nelle, O., Dörfler, W., Zagana, H., Nowaczyk, N., Xue, J., and Unkel, I.: Late Glacial to mid-Holocene palaeoclimate development of Southern Greece inferred from the sediment sequence of Lake Stymphalia (NE-Peloponnese), Quat. Internat., 302, 42-60, 2013.

Hongve, D.: Cycling of iron, manganese, and phosphate in a meromictic lake, Limnol. Oceanogr., 42, 635-647, 1997.

Jin, Z., Wang, S., Shen, J., Zhang, E., Li, F., Ji, J., and Lu, X.: Chemical weathering since the Little Ice Age recorded in lake sediments: a high-resolution proxy of past climate, Earth Surf. Proc. Landforms, 26, 775-782, 2001.

Johnson, T. C., Brown, E. T., and Shi, J.: Biogenic silica deposition in Lake Malawi, East Africa over the past 150000 years, Palaeogeography, Palaeoclimatology, Palaeoecology, 303, 103-109, , 2011.

Juschus, O., Preusser, F., Melles, M., and Radtke, U.: Applying SAR-IRSL methodology for dating fine-grained sediments from lake El'gygytgyn, north-eastern Siberia, Quat. Geochronol., 2, 187-194, 2007.

Juschus, O., Pavlov, M., Schwamborn, G., Preusser, F., Fedorov, G., and Melles, M.: Late Quaternary lake-level changes of Lake El'gygytgyn, NE Siberia, Quat. Res., 76, 441-451, 2011.

Kalugin, I., Daryin, A., Smolyaninova, L., Andreev, A., Diekmann, B., and Khlystov, O.: 800-yr-long records of annual air tempera- 
ture and precipitation over southern Siberia inferred from Teletskoye Lake sediments, Quat. Res., 67, 400-410, 2007.

Koenig, S. J., Deconto, R. M., and Pollard, D.: Late Pliocene to Pleistocene sensitivity of the Greenland Ice Sheet in response to external forcing and internal feedbacks, Clim. Dynam., 37, 1247-1268, 2011.

Koinig, K. A., Shotyk, W., Lotter, A. F., Ohlendorf, C., and Sturm, M.: 9000 years of geochemical evolution of lithogenic major and trace elements in the sediment of an alpine lake - the role of climate, vegetation, and land-use history, J. Paleolimnol., 30, 307$320,2003$.

Kujau, A., Nürnberg, D., Zielhofer, C., Bahr, A., and Röhl, U.: Mississippi River discharge over the last $\sim 560000$ years - Indications from X-ray fluorescence core-scanning, Palaeogeography, Palaeoclimatology, Palaeoecology, 298, 311-318, 2010.

Kylander, M., Muller, J., Wust, R., Gallagher, K., Garciasanchez, R., Coles, B., and Weiss, D.: Rare earth element and $\mathrm{Pb}$ isotope variations in a $52 \mathrm{kyr}$ peat core from Lynch's Crater (NE Queensland, Australia): Proxy development and application to paleoclimate in the Southern Hemisphere, Geochimica et Cosmochimica Acta, 71, 942-960, 2007.

Kylander, M. E., Ampel, L., Wohlfarth, B., and Veres, D.: Highresolution X-ray fluorescence core scanning analysis of Les Echets (France) sedimentary sequence: new insights from chemical proxies, J. Quat. Sci., 26, 109-117, 2011.

Laskar, J., Robutel, P., Joutel, F., Gastineau, M., Correia, A. C. M., and Levrard, B.: A long-term numerical solution for the insolation quantities of the Earth, A\&A, 428, 261-285, 2004.

Lawrence, K. T., Herbert, T. D., Brown, C. M., Raymo, M. E., and Haywood, A. M.: High-amplitude variations in North Atlantic sea surface temperature during the early Pliocene warm period, Paleoceanography, 24, PA2218, 2009.

Layer, P. W.: Argon-40/argon-39 age of the El'gygytgyn impact event, Chukotka, Russia, Meteorit. Planet. Sci., 35, 591-599, 2000.

Lisiecki, L. E. and Raymo, M. E.: A Pliocene-Pleistocene stack of 57 globally distributed benthic $\delta^{1} 8 \mathrm{O}$ records, Paleoceanography, 20, PA1003, doi:10.1029/2004pa001071, 2005.

Löwemark, L., Chen, H. F., Yang, T. N., Kylander, M., Yu, E. F., Hsu, Y. W., Lee, T. Q., Song, S. R., and Jarvis, S.: Normalizing XRF-scanner data: A cautionary note on the interpretation of high-resolution records from organic-rich lakes, J. Asian Earth Sci., 40, 1250-1256, 2011.

Lozhkin, A. V., Anderson, P. M., Matrosova, T. V., and Minyuk, P. S.: The pollen record from El'gygytgyn Lake: implications for vegetation and climate histories of northern Chukotka since the late middle Pleistocene, J. Paleolimnol., 37, 135-153, 2007a.

Lozhkin, A. V., Anderson, P. M., Matrosova, T. V., Minyuk, P. S., Brigham-Grette, J., and Melles, M.: Continuous Record of Environmental Changes in Chukotka during the Last 350 Thousand Years, Russ. J. Pacific Geol., 1, 550-555, 2007b.

Martínez-Garcia, A., Rosell-Melé, A., McClymont, E. L., Gersonde, R., and Haug, G. H.: Subpolar Link to the Emergence of the Modern Equatorial Pacific Cold Tongue, Science, 328, 15501553, 2010.

März, C., Schnetger, B., and Brumsack, H. J.: Nutrient leakage from the North Pacific to the Bering Sea (IODP Site U1341) following the onset of Northern Hemispheric Glaciation?, Paleoceanography, 28, 68-78, 2013.
Melles, M., Brigham-Grette, J., Glushkova, O. Y., Minyuk, P. S., Nowaczyk, N. R., and Hubberten, H. W.: Sedimentary geochemistry of core PG1351 from Lake El'gygytgyn - a sensitive record of climate variability in the East Siberian Arctic during the past three glacial-interglacial cycles, J. Paleolimnol., 37, 89-104, 2007.

Melles, M., Brigham-Grette, J., Minyuk, P., Koeberl, C., Andreev, A., Cook, T., Fedorov, G., Gebhardt, C., Haltia-Hovi, E., Kukkonen, M., Nowaczyk, N., Schwamborn, G., Wennrich, V., and and the El'gygytgyn Scientific Party: The Lake El'gygytgyn Scientific Drilling Project - Conquering Arctic Challenges through Continental Drilling, Scient. Drill., 11, 29-40, 2011.

Melles, M., Brigham-Grette, J., Minyuk, P. S., Nowaczyk, N. R., Wennrich, V., DeConto, R. M., Anderson, P. M., Andreev, A. A., Coletti, A., Cook, T. L., Haltia-Hovi, E., Kukkonen, M., Lozhkin, A. V., Rosen, P., Tarasov, P., Vogel, H., and Wagner, B.: 2.8 Million Years of Arctic Climate Change from Lake El'gygytgyn, NE Russia, Science, 337, 315-320, 2012.

Meyer-Jacob, C., Vogel, H., Melles, M., and Rosén, P.: Biogeochemical properties and diagenetic changes during the past 3.6 Ma recorded by FTIR spectroscopy in the sediment record of Lake El'gygytgyn, Far East Russian Arctic, Clim. Past Discuss., 9, 2489-2515, doi:10.5194/cpd-9-2489-2013, 2013.

Minyuk, P. S., Brigham-Grette, J., Melles, M., Borkhodoev, V. Y., and Glushkova, O. Y.: Inorganic geochemistry of El'gygytgyn Lake sediments (northeastern Russia) as an indicator of paleoclimatic change for the last $250 \mathrm{kyr}$, J. Paleolimnol., 37, 123-133, 2007.

Minyuk, P. S., Borkhodoev, V. Y., and Goryachev, N. A.: Geochemical characteristics of sediments from Lake El'gygytgyn, Chukotka Peninsula, as indicators of climatic variations for the past 350 ka, Doklady Earth Sci., 436, 94-97, 2011.

Minyuk, P. S., Subbotnikova, T. V., Brown, L. L., and Murdock, K. J.: High-temperature thermomagnetic properties of vivianite nodules, Lake El'gygytgyn, Northeast Russia, Clim. Past, 9, 433-446, doi:10.5194/cp-9-433-2013, 2013.

Minyuk, P. S., Borkhodoev, V. Y., and Wennrich, V.: Inorganic geochemistry data from Lake El'gygytgyn sediments: marine isotope stages 6-11, Clim. Past, 10, 467-485, doi:10.5194/cp-10467-2014, 2014.

Mottaghy, D., Schwamborn, G., and Rath, V.: Past climate changes and permafrost depth at the Lake El'gygytgyn site: implications from data and thermal modeling, Clim. Past, 9, 119-133, doi:10.5194/cp-9-119-2013, 2013.

Murdock, K. J., Wilkie, K., and Brown, L. L.: Rock magnetic properties, magnetic susceptibility, and organic geochemistry comparison in core LZ1029-7 Lake El'gygytgyn, Russia Far East, Clim. Past, 9, 467-479, doi:10.5194/cp-9-467-2013, 2013.

Naeher, S., Gilli, A., North, R. P., Hamann, Y., and Schubert, C. J.: Tracing bottom water oxygenation with sedimentary $\mathrm{Mn} / \mathrm{Fe}$ ratios in Lake Zurich, Switzerland, Chem. Geol., 352, 125-133, 2013.

Naish, T., Powell, R., Levy, R., Wilson, G., Scherer, R., Talarico, F., Krissek, L., Niessen, F., Pompilio, M., Wilson, T., Carter, L., DeConto, R., Huybers, P., McKay, R., Pollard, D., Ross, J., Winter, D., Barrett, P., Browne, G., Cody, R., Cowan, E., Crampton, J., Dunbar, G., Dunbar, N., Florindo, F., Gebhardt, C., Graham, I., Hannah, M., Hansaraj, D., Harwood, D., Helling, D., Henrys, S., Hinnov, L., Kuhn, G., Kyle, P., Laufer, A., Maffioli, P., Ma- 
gens, D., Mandernack, K., McIntosh, W., Millan, C., Morin, R., Ohneiser, C., Paulsen, T., Persico, D., Raine, I., Reed, J., Riesselman, C., Sagnotti, L., Schmitt, D., Sjunneskog, C., Strong, P., Taviani, M., Vogel, S., Wilch, T., and Williams, T.: Obliquity-paced Pliocene West Antarctic ice sheet oscillations, Nature, 458, 322328, 2009.

Nolan, M.: Quantitative and qualitative constraints on hind-casting the formation of multiyear lake-ice covers at Lake El'gygytgyn, Clim. Past, 9, 1253-1269, doi:10.5194/cp-9-1253-2013, 2013.

Nolan, M. and Brigham-Grette, J.: Basic hydrology, limnology, and meteorology of modern Lake El'gygytgyn, Siberia, J. Paleolimnol., 37, 17-35, 2007.

Nolan, M., Liston, G., Prokein, P., Brigham-Grette, J., Sharpton, V. L., and Huntzinger, R.: Analysis of lake ice dynamics and morphology on Lake El'gygytgyn, NE Siberia, using synthetic aperture radar (SAR) and Landsat, J. Geophys. Res. (Atmos.), 108, 8162, doi:10.1029/2001JD000934, 2003.

Nowaczyk, N. R., Minyuk, P., Melles, M., Brigham-Grette, J., Glushkova, O., Nolan, M., Lozhkin, A. V., Stetsenko, T. V., Andersen, P. M., and Forman, S. L.: Magnetostratigraphic results from impact crater lake El'gygytgyn, northeastern Siberia: a possibly 300 kyr long terrestrial paleoclimate record from the Arctic, Geophys. J. Internat., 150, 109-126, 2002.

Nowaczyk, N. R., Melles, M., and Minyuk, P.: A revised age model for core PG1351 from Lake El'gygytgyn, Chukotka, based on magnetic susceptibility variations tuned to northern hemisphere insolation variations, J. Paleolimnol., 37, 65-76, 2007.

Nowaczyk, N. R., Haltia, E. M., Ulbricht, D., Wennrich, V., Sauerbrey, M. A., Rosén, P., Vogel, H., Francke, A., MeyerJacob, C., Andreev, A. A., and Lozhkin, A. V.: Chronology of Lake El'gygytgyn sediments - a combined magnetostratigraphic, palaeoclimatic and orbital tuning study based on multiparameter analyses, Clim. Past, 9, 2413-2432, doi:10.5194/cp-92413-2013, 2013.

Ohlendorf, C., Gebhardt, A. C., Hahn, A., Kliem, P., Zolitschka, B., and the PASADO science team: The PASADO core processing strategy - A proposed new protocol for sediment core treatment in multidisciplinary lake drilling projects, Sediment. Geol., 239, 104-115, 2011.

Ohlendorf, C., Wennrich, V., and Enters, D.: Experiences with XRF-scanning of long sediment records, in: Micro-XRF studies of sediment cores - A non-destructive tool for the environmental sciences., edited by: Rothwell, G., and Croudace, I., Develop. Paleoenviron. Res. Ser., Springer, in press, 2014.

Panizzo, V. N., Jones, V. J., Birks, H. J. B., Boyle, J. F., Brooks, S. J., and Leng, M. J.: A multiproxy palaeolimnological investigation of Holocene environmental change, between ca. 10700 and 7200 years BP, at Holebudalen, southern Norway, The Holocene, 18, 805-817, 2008.

Peinerud, E. K.: Interpretation of Si concentrations in lake sediments: three case studies, Environ. Geol., 40, 64-72, 2000.

Raschke, U., Reimold, W. U., Zaag, P. T., Pittarello, L., and Koeberl, C.: Lithostratigraphy of the impactite and bedrock section of ICDP drill core D1c from the El'gygytgyn impact crater, Russia, Meteorit. Planet. Sci., 48, 1143-1159, 2013a.

Raschke, U., Schmitt, R. T., and Reimold, W. U.: Petrography and geochemistry of impactites and volcanic bedrock in the ICDP drill core D1c from Lake El'gygytgyn, NE Russia, Meteorit. Planet. Sci., 48, 1251-1286, 2013b.
Rothwell, R. G. and Rack, F. R.: New techniques in sediment core analysis: an introduction, Geol. Soc., London, Special Publications, 267, 1-29, 2006.

Sauerbrey, M. A., Juschus, O., Gebhardt, A. C., Wennrich, V., Nowaczyk, N. R., and Melles, M.: Mass movement deposits in the 3.6 Ma sediment record of Lake El'gygytgyn, Far East Russian Arctic, Clim. Past, 9, 1949-1967, 2013,

http://www.clim-past.net/9/1949/2013/.

Schulz, M. and Mudelsee, M.: REDFIT: estimating red-noise spectra directly from unevenly spaced paleoclimatic time series, Comput. Geosci., 28, 421-426, 2002.

Schwamborn, G., Meyer, H., Fedorov, G., Schirrmeister, L., and Hubberten, H.-W.: Ground ice and slope sediments archiving late Quaternary paleoenvironment and paleoclimate signals at the margins of El'gygytgyn Impact Crater, NE Siberia, Quat. Res., 66, 259-272, 2006.

Schwamborn, G., Fedorov, G., Schirrmeister, L., Meyer, H., and Hubberten, H. W.: Periglacial sediment variations controlled by late Quaternary climate and lake level change at Elgygytgyn Crater, Arctic Siberia, Boreas, 37, 55-65, 2008a.

Schwamborn, G., Förster, A., Diekmann, B., Schirrmeister, L., and Fedorov, G.: Mid- to Late-Quaternary Cryogenic Weathering Conditions at Elgygytgyn Crater, Northeastern Russia: Inference from Mineralogical and Microtextural Properties of the Sediment Record, Ninth International Conference On Permafrost, Fairbanks, 1601-1606, 2008b.

Shuster, D. L., Ehlers, T. A., Rusmoren, M. E., and Farley, K. A.: Rapid Glacial Erosion at $1.8 \mathrm{Ma}$ Revealed by $4 \mathrm{He} / 3 \mathrm{He}$ Thermochronometry, Science, 310, 1668-1670, 2005.

Snyder, J. A., Cherepanova, M. V., and Bryan, A.: Dynamic diatom response to changing climate 0-1.2 Ma at Lake El'gygytgyn, Far East Russian Arctic, Clim. Past, 9, 1309-1319, doi:10.5194/cp9-1309-2013, 2013.

Swann, G. E. A., Leng, M. J., Juschus, O., Melles, M., BrighamGrette, J., and Sloane, H. J.: A combined oxygen and silicon diatom isotope record of Late Quaternary change in Lake El'gygytgyn, North East Siberia, Quat. Sci. Rev., 29, 774-786, 2010.

Tarasov, P. E., Andreev, A. A., Anderson, P. M., Lozhkin, A. V., Haltia, E., Nowaczyk, N. R., Wennrich, V., Brigham-Grette, J., and Melles, M.: The biome reconstruction approach as a tool for interpretation of past vegetation and climate changes: application to modern and fossil pollen data from Lake El'gygytgyn, Far East Russian Arctic, Clim. Past Discuss., 9, 3449-3487, doi:10.5194/cpd-9-3449-2013, 2013.

Teraishi, A., Suto, I., Onodera, J., and Takahashi, K.: Diatom, silicoflagellate and ebridian biostratigraphy and paleoceanography in IODP 323 Hole U1343E at the Bering slope site, Deep Sea Res. Pt. II, doi:10.1016/j.dsr2.2013.03.026, 2014.

Vogel, H., Meyer-Jacob, C., Melles, M., Brigham-Grette, J., Andreev, A. A., Wennrich, V., Tarasov, P. E., and Rosén, P.: Detailed insight into Arctic climatic variability during MIS 11c at Lake El'gygytgyn, NE Russia, Clim. Past, 9, 1467-1479, doi:10.5194/cp-9-1467-2013, 2013.

Weber, M. E., Tougiannidis, N., Kleineder, M., Bertram, N., Ricken, W., Rolf, C., Reinsch, T., and Antoniadis, P.: Lacustrine sediments document millennial-scale climate variability in northern Greece prior to the onset of the northern hemisphere glaciation, Palaeogeogr. Palaeocl. 291, 360-370, 2010. 
Wennrich, V., Francke, A., Dehnert, A., Juschus, O., Leipe, T., Vogt, C., Brigham-Grette, J., Minyuk, P. S., Melles, M., and El'gygytgyn Science, P.: Modern sedimentation patterns in Lake El'gygytgyn, NE Russia, derived from surface sediment and inlet streams samples, Clim. Past, 9, 135-148, doi:10.5194/cp-9-1352013, 2013.

Whitlock, C., Dean, W., Rosenbaum, J., Stevens, L., Fritz, S., Bracht, B., and Power, M.: A 2650-year-long record of environmental change from northern Yellowstone National Park based on a comparison of multiple proxy data, Quat. Internat., 188, 126-138, 2008.
Yanase, W. and Abe-Ouchi, A.: The LGM surface climate and atmospheric circulation over East Asia and the North Pacific in the PMIP2 coupled model simulations, Clim. Past, 3, 439-451, doi:10.5194/cp-3-439-2007, 2007.

Yancheva, G., Nowaczyk, N. R., Mingram, J., Dulski, P., Schettler, G., Negendank, J. F., Liu, J., Sigman, D. M., Peterson, L. C., and Haug, G. H.: Influence of the intertropical convergence zone on the East Asian monsoon, Nature, 445, 74-77, 2007. 